NBER WORKING PAPER SERIES

\title{
WHY DOES CAPITAL NO LONGER FLOW MORE TO THE INDUSTRIES WITH THE BEST GROWTH OPPORTUNITIES?
}

\author{
Dong Lee \\ Han Shin \\ René M. Stulz \\ Working Paper 22924 \\ http://www.nber.org/papers/w22924 \\ NATIONAL BUREAU OF ECONOMIC RESEARCH \\ 1050 Massachusetts Avenue \\ Cambridge, MA 02138 \\ December 2016
}

Lee is from Korea University Business School, Shin is from School of Business at Yonsei University, and Stulz is from the Fisher School of Business, Ohio State University, NBER, and ECGI. We are grateful for comments from Heitor Almeida, Sergey Chernenko, Harry DeAngelo, Andrei Gonçalves, Luke Taylor, Toni Whited, and participants at a seminar at Ohio State. The views expressed herein are those of the authors and do not necessarily reflect the views of the National Bureau of Economic Research.

At least one co-author has disclosed a financial relationship of potential relevance for this research. Further information is available online at http://www.nber.org/papers/w22924.ack

NBER working papers are circulated for discussion and comment purposes. They have not been peer-reviewed or been subject to the review by the NBER Board of Directors that accompanies official NBER publications.

(C) 2016 by Dong Lee, Han Shin, and René M. Stulz. All rights reserved. Short sections of text, not to exceed two paragraphs, may be quoted without explicit permission provided that full credit, including $\odot$ notice, is given to the source. 
Why Does Capital No Longer Flow More to the Industries with the Best Growth Opportunities?

Dong Lee, Han Shin, and René M. Stulz

NBER Working Paper No. 22924

December 2016

JEL No. E22,E44,G31,G35,L16

\section{ABSTRACT}

With functionally efficient capital markets, we expect capital to flow more to the industries with the best growth opportunities. As a result, these industries should invest more and see their assets grow more relative to industries with the worst growth opportunities. We find that industries that receive more funds have a higher industry Tobin's q until the mid-1990s, but not since then. Since industries with a higher funding rate grow more, there is a negative correlation not only between an industry's funding rate and industry q but also between capital expenditures and industry q since the mid-1990s. We show that capital no longer flows more to the industries with the best growth opportunities because, since the middle of the 1990s, firms in high q industries increasingly repurchase shares rather than raise more funding from the capital markets.

Dong Lee

Korea University Business School 523 Hyundai Motor Hall

Seoul, Korea 02841

donglee@korea.ac.kr

Han Shin

Yonsei University

School of Business

632 School of Business Bldg

Seoul, Korea 03722

hhanshin@gmail.com
René M. Stulz

The Ohio State University

Fisher College of Business

806A Fisher Hall

Columbus, OH 43210-1144

and NBER

stulz@cob.osu.edu 


\section{Introduction}

In market economies, a critical role of capital markets is to allocate capital across industries and firms. Tobin (1984) uses the concept of functional efficiency to describe capital markets that allocate capital to its best use. With functionally efficient capital markets, we expect capital to flow towards the industries with the best opportunities and away from the industries with the poorest opportunities. Bagehot, in 1873, already observed that in England "capital runs as surely and instantly where it is most wanted, and where there is most to be made of it, as water runs to find its level." ${ }^{\text {M }}$ More recently, Wurgler (2000) provides evidence that capital is allocated more efficiently across industries in countries with a more developed financial sector. However, following the collapse of the telecoms and the dot.coms at the beginning of the 2000s and the global financial crisis more recently, many argue that financial markets are not very good at allocating capital (e.g., Foroohar (2016)). Further, many studies in finance provide evidence of how mispricing of a firm's stock affects its level of investment through a financing channel, such as stock issuance (see Baker and Wurgler (2013) for a survey of the literature).

In this paper, we examine whether capital flows more to the industries with the best opportunities from 1971 to 2014. We call an industry's funding rate the industry's ratio of new capital provided by the capital markets to assets. Assuming that a proxy for an industry's Tobin's q measures the industry's growth opportunities, we find that, until the middle of the 1990s, the industries with the highest funding rates were industries with better growth opportunities relative to the lowest funding rate industries, as expected for functionally efficient capital markets. After the middle of the 1990s, capital no longer flows more to the industries with the best growth opportunities. From the middle of the 1990s until 2014, industries with the lowest funding rates have better growth opportunities than the industries with the highest funding rates. We show that this change is entirely due to high q firms that invest less after the middle of the 1990s and use the resulting excess cash flow to repurchase shares. Without these firms, there is a positive correlation

\footnotetext{
${ }^{1}$ Bagehot's quote is reported by Levine (1997), p. 695.
} 
between an industry's funding rate and its growth opportunities throughout the sample period rather than only before the middle of the 1990s. We reach these conclusions using Tobin's q as a measure of industry growth opportunities, which is defined as the ratio of the market value of the assets of the industry divided by their book value. As we rely on the use of medians and non-parametric tests, however, our conclusions are less sensitive to Tobin's q mismeasurement than typical parametric approaches. Nevertheless, we confirm that our conclusions are robust using Tobin's q estimates that account for intangibles and are not an artifact of measurement error in Tobin's q.

To measure the rate at which capital flows to an industry, we sum the net long-term debt issuance and net equity issuance at the industry level and divide it by the industry's total assets. When the industry funding rate is positive, the industry attracts capital. In a neo-classical world, new funds should flow towards high q industries and away from low q industries. We call this the efficient capital allocation hypothesis. As a result of these financing patterns, high q industries should grow faster than low q industries and their q should fall as they take advantage of their growth opportunities. Industries that differ greatly in their performance and valuations should therefore become more similar because of how capital markets allocate funds. We call this the convergence hypothesis.

We first examine how much variation there is in the extent to which industries use external funding. We use the 48-industries classification from Fama and French (1997). For each year, from 1971 to 2014, we rank industries with ten or more firms in Compustat according to their funding rate. We then compare industries in the top quintile and the bottom quintile of that ratio. In a typical year, each industry in the bottom quintile has a negative funding rate. For our sample, the median funding rate for the industries in the bottom funding rate quintile is $-2.1 \%$. In other words, at the median, the industries in the bottom funding rate quintile have a capital outflow rather than a capital inflow. In contrast, the industries in the top funding rate quintile have a median inflow of $6.4 \%$.

With the efficient capital allocation hypothesis, we expect capital to flow more to industries with a higher q than to industries with a lower q. With the whole sample, we find that this is not the case. The 
median q of the industries in the top funding rate quintile is 1.33 . This median q is not significantly different from the median q of 1.29 for the industries in the bottom funding rate quintile. We expect the greater inflow of resources to be associated with higher capital expenditures and higher asset growth for the most funded industries in comparison to the least funded industries. We find that this is the case. The differences in capital expenditures and asset growth between the two quintiles of industries are large. For capital expenditures, the median ratio of capital expenditures to assets is $66 \%$ higher for the most highly funded industries compared to the least funded industries. Asset growth of the most highly funded industries is more than three times the asset growth of the least funded industries.

Rather than focusing on the top and bottom quintile of the funding rate, we can investigate whether the funding rate is correlated with industry $\mathrm{q}$ across all sample industries. The efficient capital allocation hypothesis predicts a positive correlation. We find that the (Spearman rank) correlation is positive every year but one from 1971 to 1995 . Since 1995, the correlation is negative in 14 years and positive in four years. This dramatic change is driven by the correlation between industry q and industry equity funding. Since 1995, the correlation between q and equity funding is negative every year but two. From 1971 to 1995, it is negative only for six years. In contrast, the correlation between q and debt funding is typically positive since 1995 as well as before.

Given the change in regime that appears to take place in the middle of the 1990s, we split our sample into two sub-periods. The first sub-period is from 1971 to the end of 1996 and the second from the end of 1996 to 2014. With this split, we find that in the first sub-period the allocation of capital is exactly what one would expect from the efficient capital allocation hypothesis. During this sub-period, the median Tobin's q of the industries that are most highly funded is $17 \%$ higher than the Tobin's q of the least funded industries (1.30 versus 1.11) and the difference is significant at the $1 \%$ level. A significant q difference emerges between the two groups of industries three years before the year when these industries are classified as most-funded and least-funded. The $\mathrm{q}$ difference disappears in year 2 after the selection year. Consequently, the evidence for q is also supportive of the convergence hypothesis before the end of 1996. 
After 1996, the pattern is opposite. The median Tobin's q of the industries that are most- funded is $15 \%$ lower than the Tobin's q of the least funded industries (1.37 versus 1.58). The difference is significant at the 5\% level and is extremely persistent as it is significant for five years after industries are assigned to the funding rate quintiles. Further, the difference five years after assignment is greater than in the year of assignment, which directly contradicts the convergence hypothesis.

The $\mathrm{q}$ theory of investment predicts that firms with a higher $\mathrm{q}$ invest more absent financial frictions. A simple way to investigate this prediction at the industry level is to estimate the correlation between an industry's investment rate and its q. For the whole sample period, industries with a higher funding rate invest more, whether or not these industries have a higher q than industries with a lower funding rate. It is therefore not surprising that the change in the relation between industry funding rates and $q$ that takes place in the middle of the 1990s is associated with a change in the relation between industry investment and industry q. Until 1996, industry investment increases with q as expected. After 1996, the correlation between industry investment and industry q is negative almost every year.

Further, the least funded industries not only have a high q but also a high cash flow. Industries that reduce investment substantially but do not experience a drop in cash flow have a surplus of funds. On average, however, these industries have a negative funding rate. Industries can have negative net funding if they use their cash flow to return funds to investors. Consequently, the industries with a high q but a low funding rate after 1996 are the industries with a large repurchase rate made possible by an excess of cash flow over investment brought about by a decrease in investment.

To further show the critical role of repurchases in our results, we construct yearly industry portfolios without firms that repurchase their stock that year. After excluding repurchasing firms, we find that there is no evidence of a change in the correlation between industry q and the industry funding rate after 1996. Specifically, if we exclude repurchasing firms, the efficient capital allocation hypothesis is supported throughout the sample period. Hence, if industry valuations are unbiased, the reason capital markets allocate 
capital in a way that seems inefficient after 1996 is because of the firms that choose to devote funds to repurchase shares instead of using those funds to invest.

The existing literature shows, building on Wurgler (2000), that more developed financial markets allocate capital more efficiently. He studies the responsiveness of industry investment to industry value added across a large sample of countries and concludes that this responsiveness is much higher in countries with high financial development. As a result, there is now a large literature that, following Rajan and Zingales (1998), takes the U.S. capital allocation across industries as the benchmark for an efficient allocation. The allocation of capital after 1996 in the U.S. is not consistent with the simple version of the efficient capital allocation hypothesis we test. Hoberg and Phillips (2010) document the existence of booms and busts at the industry level in the U.S. With their evidence, high valuations are followed by poor returns. Their evidence is supportive of the view that at times industries misallocate capital because of potential misvaluation. Though our evidence builds on theirs, the important difference is that we focus on how capital markets allocate capital across industries and document a systematic change in that allocation after the mid1990s.

One might be tempted to argue that a possible explanation for our evidence could be that the capital market price signals are wrong after the mid-1990s, so that the financial markets ignore these signals when they allocate capital. The problem with this explanation for our findings is that the firms that repurchase are highly valued, a phenomenon noticed earlier in the literature, for instance by Dittmar and Dittmar (2004). We would not expect firms to repurchase massive amounts of their stock if the market overvalues that stock. Rather, we would expect such firms to use their over-priced equity to raise more capital and invest more (see Stein (1996) for an analysis of the implications of misvaluation for capital budgeting and references) or make more acquisitions (Shleifer and Vishny (2003)). Hence, our evidence is equally puzzling if valuation signals are correct throughout our sample period or only before the middle of the 1990s.

In a contemporaneous paper, Gutiérrez and Philippon (2016) show that investment falls in the early 2000s and explore possible explanations for this fall. They find strong support for two potential 
explanations. The first explanation is that competition has decreased, which implies that firms invest less than predicted by the q-theory of investment. The second explanation is a governance explanation, where greater institutional ownership by quasi-index funds leads to greater payouts and less investment.

The paper proceeds as follows. In Section 2, we explain our sample and data. Sections 3 and 4, respectively, test the efficient capital allocation hypothesis and the convergence hypothesis. In Section 5, we examine the equity and debt funding rates separately. Section 6 investigates the role of firms that repurchase stock in our results. Section 7 concludes.

\section{Data and funding rate}

We begin with all Compustat firms (in the February 2016 file) and then keep only U.S. firms, which are identified by their ISO country code in Compustat. We also require firms to have a positive value for total assets to be included in our sample in a given year. For industry classification, we first use the historical SIC code in Compustat. If that information is missing, we seek the historical SIC code in CRSP. The matching between Compustat and CRSP is based on the WRDS link table. If the CRSP historical SIC code is also missing, we then use the header SIC code in Compustat. We drop firms that do not have any of those SIC data items available, and also exclude firms whose SIC code is between 6000 and 6999 (financials) or between 4900 and 4999 (utilities). Additionally, regulated industries, as identified by Barclay and Smith (1995), are excluded from the sample. ${ }^{2}$ The remaining firms are assigned to one of the Fama and French 48 industries. Companies that do not belong to any of those 48 industry groups are dropped from the sample. Finally, we require an industry group to have at least 10 firms in a given year.

Our selection criteria give us 205,622 firm-year observations and 1,736 industry-year observations during our study period of 1971-2014 (fiscal years). Table 1 presents summary statistics for our sample. Column (2) shows the number of firms each year, which averages to 4,673 sample firms per year. The

\footnotetext{
${ }^{2}$ Those industries are railroads (SIC 4011) and trucking industry (SIC 4210 or 4213) up to 1980, airline industry (SIC 4512) up to 1978, and telecommunications industry (SIC 4812 or 4813) up to 1982.
} 
number of industries with at least 10 usable firms does not change much over time as it ranges between 37 and 41 during the sample period (Column (3)).

Our key variable is the funding raised in external capital markets. Equity funding during a year is computed as the sale of common stock and preferred stock minus the purchase of common and preferred stock. Debt funding is the issuance of long-term debt minus the reduction in long-term debt. When any of those funding data items are missing, we treat them as zero. ${ }^{3}$ Total funding is the sum of equity and debt funding. The funding rate in a given year is the ratio of the total funds raised during the year to the beginning-of-year total assets. The funding rate of an industry is the sum of all equity and debt funds raised by the industry's firms during the year, divided by the sum of the total assets of the firms in the industry at the start of the year.

The literature uses two different approaches to estimate net equity issuance. One approach is the one we use. The other approach is to use the change in book value of equity. In contrast to the change in book value of equity, the net sale measure allows us to consider equity sales and equity repurchases separately. Equity repurchases are an essential part of our analysis. The net sale measure is similar to the measure used by Jermann and Quadrini (2012), which is a measure of the exchange of equity for cash. Hence, it is the correct measure for our focus on capital flows to firms. The change in book value measure is an allencompassing measure (Fama and French (2005), Covas and den Haan (2011)) which includes any equity issuance, whether for cash or for other consideration. The change in book value measure is the right measure to consider in a study of capital structure, as it incorporates all changes in equity that affect leverage. Our focus is not on leverage but on capital flows. Nevertheless, we show that our main conclusion holds if we use the change in book value measure.

Columns (4) through (10) of Table 1 report summary statistics for the industry funding rates. The top row is for the entire sample period (i.e., across the 1,736 industry-year observations) and the other rows give year-by-year statistics. The average funding rate across industries and years is $1.8 \%$. This funding rate

\footnotetext{
${ }^{3}$ We obtain similar results if we do not use variables with missing observations instead of setting them to zero.
} 
varies substantially over time. The lowest mean is $-0.6 \%$ in 2005 and the highest is $4.9 \%$ in 1986 . Looking at differences across years, the funding rate in the 2000 s is noticeably lower than in earlier years. First, after 2001, the funding rate never exceeds $1 \%$ while before that only three years have a funding rate below this level. Second, the funding rate averages $2.5 \%$ and is never negative before 2002 but it is negative seven years since with an average of only $0.2 \%$. Finally, the $25^{\text {th }}$ funding rate percentile is negative only in $40 \%$ of the years before 1999, but it is negative in every year since then.

The last two columns, (11) and (12), show the number of industries with a negative funding rate (called the rationed industries for short) and their proportion in the sample. Only $32.6 \%$ of the industry years in the dataset have a negative funding rate. Of all years in the sample, 2011 is the year with the highest fraction of industries with negative net funding (69.2\%). There is no evidence that the fraction of industries with a negative funding rate is higher in periods of low growth. For instance, $27.5 \%$ of the industries have a negative or zero funding rate in 1997, which is a good year for the economy as well as for the stock market. In contrast, only $2.6 \%$ of the industries have a negative or zero funding rate in 1980 , which is a recession year.

Table 2 shows the frequency of positive and negative funding rates by industry. We also rank industries into quintiles by funding rates and report how often a given industry belongs to the top or bottom funding quintiles. Though we do not show this number in the table, the average over the sample period of the median funding rate for industries in the bottom funding rate quintile is $-2.1 \%$ and $6.4 \%$ for the top funding rate quintile. The composition of the top and bottom quintiles changes substantially over time. For instance, of the 43 industries in the sample, all but three industries are in the bottom funding quintile at least twice. Moreover, even though almost all industries are at least once in the top quintile of financing rates, only 11 industries belong to it more than ten times. 


\section{Do the industries with a high funding rate have higher growth opportunities?}

Our test of whether the market allocates resources efficiently is whether industries that receive more capital have better growth opportunities. For this test, we compare industries with the highest and lowest funding rates. To insure that we have substantial differences in funding rates between the comparison subsamples and that these comparison subsamples are of similar size, we choose to compare the industries in the top quintile of funding rates with the industries in the bottom quintile of funding rates. We call industries in the top quintile of funding rates the high-funded industries and the ones in the bottom quintile the low-funded industries.

Figure 1 shows the median industry q for the high-funded industries and the low-funded industries for our sample period. The industry $q$ is measured at the end of the year that precedes the funding year. It is immediately clear that a substantial change takes place in the mid-1990s. Before the mid-1990s, the median industry q for the low-funded industries is lower than the median industry q for the high-funded industries. After the mid-1990s, it is almost always the case that the median industry q of the low-funded industries is higher than the median industry q of the high-funded industries.

In Table 3, we take a closer look at the industry q differences between low-funded and high-funded industries over our sample period. With functionally efficient capital markets, we expect this difference to be negative. Strikingly, this difference is positive in 19 years. Out of these 19 years, 14 are after 1996, so that after 199614 year out of 18 or almost $80 \%$ of the years have a positive difference between the q of low-funded and high-funded industries. Before 1997, almost all years have a negative difference as expected as only 5 out of 26 years have a positive difference, or slightly less than $20 \%$. It is possible for noise to induce a positive q gap between low- and high-funded industries. To investigate this possibility, we check whether in the years that the difference is positive we can reject that it is zero or negative. In 9 of the 14 years after 1996, we can reject the hypothesis that the difference is zero or negative using the Wilcoxon test (at the 10\% level). Moreover, these separate tests do not even take into account the striking fact that the negative q gap clusters in the years after the mid-1990s. 
A different approach to investigating the relation between an industry's funding rate and its $\mathrm{q}$ is to estimate the correlation between industry $q$ and the industry funding rate. We would expect that correlation to be positive. Figure 2 plots the Spearman rank correlation for each year in our sample period. The results are supportive of the existence of a sharp change around the middle of the 1990s. Specifically, the correlation is positive every sample year until 1995 but one, which is 1990. After 1996, the correlation is negative almost every year. Using Newey-West $t$-statistics with two lags, the average correlation before 1997 is significantly positive at the $1 \%$ level on average and the average correlation after 1996 is significantly negative at the same level of significance. A concern might be that capital markets react more slowly to data about q, so that the relevant $\mathrm{q}$ is a lagged q. We investigate the correlations shown in Figure 2 lagging $\mathrm{q}$ by one or by two years. The pattern documented in Figure 2 stays the same.

In summary, the relation between an industry's q and its funding rate changes drastically around the middle of the 1990s. In the 25 sample years before 1996, the high-funded industries (top funding rate quintile) tend to have a higher q than the low-funded industries (bottom funding rate quintile). Further, there is a positive correlation between industry q and the funding rate across all sample industries. After 1996, the opposite occurs: the high-funded industries have a lower q than the low-funded industries and the crossindustry correlation between industry $\mathrm{q}$ and the industry funding rate is negative.

One might be tempted to argue that such a change is due to the fact that our sample period includes the period in the late 1990s and early 2000s when valuations are extremely high and often considered to be unrelated to fundamentals. However, this explanation does not work in that the highest negative correlations between industry q and industry funding rate in absolute value are, in order, in 2014, 2013, 2005, and 2008. All these years are far removed from the high valuation years of the late 1990s and early 2000s. When we look at the differences in industry q between the high-funded quintile and the low-funded quintile, the difference in 1999, the highest-valuation year, is only ranked fifth.

Another potential concern with our results is that intangible assets have become more important for American firms and book assets do not account for intangible assets acquired organically. Peters and Taylor 
(2016) show that Tobin's q can be estimated accounting for intangible assets. We use their approach to incorporate intangibles in Tobin's q estimates. They define the q ratio without intangibles as the ratio of the market value of equity plus the book value of long-term and short-term debt minus the book value of current assets to the book value of property, plant, and equipment. The q ratio with intangibles is similarly defined, except that the denominator additionally includes the value of intangible assets, which we obtain from Peters and Taylor (2016). Figure 3 shows the annual (Spearman rank) correlation between the total funding rate and Tobin's q for the two definitions of Tobin's q. Accounting for intangibles changes the sign of the correlation in 10 years. Most of these changes are after 1996, but in five cases the correlation becomes positive and in three it becomes negative. Overall, using their approach to account for intangibles in estimating Tobin's q does not change our conclusions as the correlation between Tobin's q and the total funding rate is negative in 11 years after 1996 when we account for intangibles and one year before.

A final issue is whether our results differ if we use the change in equity book value as our measure of equity issuance. We believe that our net sales equity issuance measure is more appropriate for our purpose. However, if we use the change in book value measure, we find that from 1971 to 1996, the correlation between the total funding rate and equity q is zero or positive 18 times and negative eight times, so that $69 \%$ of the observations are non-negative. It is notable that six of the first seven observations are negative, so that from 1978 to 1996, only two observations are negative. From 1997 to 2014, the correlation is positive five years and negative 13 years, so that only $28 \%$ of observations are positive.

\section{Testing the convergence hypothesis}

With functionally efficient capital markets, we expect low-funded industries to have a lower q than high-funded industries. Because of the funding difference, the high-funded industries grow more than the low-funded industries, so that eventually the Tobin's q of the industries converge. In this section, we investigate the dynamics of the Tobin's q and other characteristics of high-funded industries and lowfunded industries. In particular, we explore how an industry's characteristics change around the time when 
it is included either in the low-funded industry group or the high-funded industry group. We perform the analysis separately for each sub-period. Given the sharp difference between the first and the second subperiods, there is no point in showing results for the whole sample period.

For this examination, we use an event study approach where year 0 is the year when an industry is either in the top or the bottom quintile of industry funding rates. More precisely, for each year $\mathrm{t}$, we rank the funding rate of industries and assign them to quintiles. For the top and bottom quintiles, we show industry characteristics from year $t-5$ to $t+5$ by computing the median value of each of the 11 years within the funding quintiles and report the average of these medians. By using medians, we reduce the impact of outliers and of mismeasurement. We also report the test results based on the median of the medians. Since we want data to be available both for $t-5$ and $t+5$, we cannot assign industries to quintiles for every sample year. Instead, the first assignment year is 1976 and the last is 2009. We examine first the evolution of industry characteristics around the assignment year for assignment years from 1976 to 1996. We then show results for assignment years from 1997 to 2009.

\subsection{Dynamics of industry characteristics around assignment years before 1997}

Panel A of Table 4 shows the evolution of industry characteristics around the assignment year for assignments until 1996. For each characteristic, we show its evolution from year -5 before assignment to year +5 after assignment for the low-funded industries and the high-funded industries. The first characteristic shown is the industry funding rate. Not surprisingly, there is a large difference in the funding rate between low-funded industries and high-funded industries. The funding rate difference between lowfunded industries and high-funded industries is negative and significant from -5 to +5 , but the difference follows a $\mathrm{u}$ shape. At $\mathrm{t}-5$, the difference is $-1.4 \%$. The difference becomes more negative and peaks in absolute value at $-8.9 \%$ in the assignment year. After that year, the difference falls in absolute value so that it is $-1.1 \%$ in year +5 . 
To examine whether there is industry q convergence, we show in Panel A of Table 4 the evolution of industry q for the low-funded and high-funded quintiles. As expected, the industry q of high-funded industries is higher in the year of assignment than the industry q of the low-funded industries. Specifically, industry q for the low-funded group in year 0 is 1.11 and industry q for the highly-funded group is 1.30 . The difference is 0.19 , so that the industry q of the high-funded group is $18 \%$ higher than the industry q of the low-funded group. The q difference is no longer significant after year +1 and is trivially small in year +5 (-0.02). Consequently, the industry q difference eventually converges to 0 , which supports the convergence hypothesis. However, surprisingly, this convergence is achieved through an increase in the Tobin's q of the low-funded industries that is not accompanied by a decrease in the Tobin's q of the highfunded industries.

We consider next three measures of industry growth. We would expect higher q industries to invest more, to experience more growth in the number of firms, and to have more asset growth. However, as the high-funded industries receive more funds, the marginal productivity of investment should fall, so that their growth should become more similar to the growth of the low-funded industries. We find strong evidence in support of this convergence hypothesis for asset growth and moderate support for growth in the number of firms and for the capital expenditures ratio.

Elaborating on capital expenditures, we find that low-funded industries have capital expenditures of $6.8 \%$ of assets in year 0 . This is the smallest rate of capital expenditures for these industries from -5 to +5 . In contrast, the high-funded industries have capital expenditures of $11.9 \%$ of assets in year 0 and this is the highest rate of capital expenditures for these industries over the event window. The difference in capital expenditures between low and high-funded industries is always negative and significant, displaying moderate convergence with the absolute difference decreasing from $5.1 \%$ in year 0 to $2.3 \%$ by year +5 .

Turning to the change in the number of firms, we see that the high-funded industries experience a greater increase in the number of firms than the low-funded industries. The difference is large and significant in years 0 and +1 (respectively $-3.4 \%$ and $-5.4 \%$ ), but it decreases substantially after and is only 
$-0.9 \%$ by year +4 . However, it increases back to $-3 \%$ in year +5 , which suggests that there is only moderate convergence for the growth in the number of firms.

Finally, we turn to the growth in assets. The asset growth differential between high-funded and lowfunded industries is extremely large $(-14.2 \%)$ in year 0 , but that difference is to a large extent driven by their mechanical difference in external funding in year 0 . By year +1 , the difference is still large $(-7.6 \%)$ and not mechanical. However, we see that the asset growth rate decreases sharply, reaching an insignificant $-2.6 \%$ by year +5 .

A concern is that low-funded industries cannot invest because they are financially constrained and cannot raise funds. This does not appear to be the case. Low-funded industries have a significantly higher dividend payout rate in the year of assignment than the high-funded industries. Consequently, low-funded industries could invest more by reducing their dividend payout to the level of the high-funded industries, or even lower.

Using operating income as a criterion, we find that the high-funded industries are most profitable in the year of assignment. In contrast, the low-funded industries are least profitable in year t-2. The profitability of the high-funded industries follows an inverted u-shape so that the difference in profitability between low-funded industries and high-funded industries is only significant in years -3 to 0 . This evolution of profitability is consistent with q-theory in that the profitability rate should fall as firms invest more.

Lastly, we look at cash flow. Perhaps not surprisingly given that they are more profitable, the highfunded industries have higher cash flow in the year of assignment than the low-funded industries. However, the difference is $0.7 \%$ of assets. Such a difference is small compared to the $5.1 \%$ difference in capital expenditures or the $14.2 \%$ difference in asset growth. It follows that this difference in cash flow cannot come close to fund the difference in capital expenditures or in asset growth. Surprisingly, however, lowfunded industries have significantly lower cash flow than high-funded industries until year 0 , but not after. After year 0, low-funded industries have higher cash flow than high-funded industries, but the difference is only significant in year +3 . This result is reminiscent of the result in Hoberg and Phillips (2010) that 
industries with high valuations and high financing have lower operating cash flow subsequently than industries with low valuations and low financing in competitive industries.

4.2. Dynamics of industry characteristics around assignment years from 1997 to 2009

We already know that, though low-funded industries have a lower q than high-funded industries until 1996, this is not the case after 1996. We now show how industry characteristics evolve in event time for assignment years after 1996. These results are presented in Table 4, Panel B.

As in Panel A, there is an extremely large difference in the funding rate between low and high-funded industries (-9.1\% here). As before, the difference follows a u shape around the assignment year. Here, the difference is only significant from -2 to +4 . In other words, funding rates converge. Surprisingly, however, we find that industry qs do not converge for assignment years after 1996. In fact, low-funded industries have a higher $q$ than high-funded industries every year from $t-5$ to $t+5$. The $q$ difference in the assignment year is one of the smallest, as it is 0.21 in the assignment year but 0.29 in year -5 and 0.28 in year +5 .

Turning to our measures of industry growth, we find first that even though high-funded industries have higher capital expenditures than low-funded ones, the difference is much smaller than in Panel A. In Panel A, the low and high-funded industries have capital expenditures of $6.8 \%$ and $11.9 \%$, respectively, in the year of assignment (difference of 5.1\%). Turning to Panel B, capital expenditures are lower both for lowfunded $(4.3 \%)$ and high-funded $(6.2 \%)$ industries, but the drop is much sharper for the high-funded industries, which leads to a differential of only $1.9 \%$ in capital expenditures. In year +5 , the high-funded industries invest $0.5 \%$ more than the low-funded ones (a difference that is significant at the $5 \%$ level). Hence, though convergence has not occurred by year +5 , the difference is smaller in year +5 than in years 0 to +4 .

As shown by Doidge, Karolyi, and Stulz (2016), the number of listed firms falls sharply after 1996. It is therefore not surprising that in Panel B the number of firms falls for both low-funded industries and highfunded industries. Except in years -1 and -2 , the difference between the low-funded and high-funded 
industries is not significant. For years -1 and -2 , the high-funded industries experience a slower rate of decrease in the number of firms.

With regard to asset growth, we find that asset growth of high-funded industries is much higher than asset growth of low-funded industries in the assignment year. As for capital expenditures, asset growth is generally lower in Panel B than in Panel A. Moreover, even though low funded industries grow $12.6 \%$ less in the assignment year, the difference quickly deteriorates and inverts with low-funded industries growing more than high-funded ones after year +1 (with +3 and +5 as statistically significant years). It follows from this that we have strong evidence of convergence for asset growth. This convergence is expected in Panel A but is surprising in Panel B since qs do not converge.

As in Panel A, the low-funded industries pay more in dividends than the high-funded ones, but the profitability evidence is quite different from Panel A. In Panel A, the high-funded industries are more profitable than the low-funded ones while in Panel B, there is no difference in profitability in the year of assignment and there is no year where the high-funded industries are significantly more profitable than the low-funded industries. Instead, every year after year 0 , the low-funded industries are more profitable than the high-funded industries. Looking at cash flows, we find a similar result. There is no year where the highfunded industries have higher cash flow than the low-funded ones, but the low-funded industries have significantly higher cash flow than the high-funded ones from year 0 to year +5 .

\subsection{A paradox}

After 1996, industry characteristics and their dynamics are opposite from what we expect: paradoxically, the low-funded industries have a higher q than the high-funded ones. Despite having a higher q, the lowfunded industries invest less and qs do not converge, so that, five years after assignment, the low-funded industries still have a higher q than the high-funded industries. Figure 4 shows that, after 1996, industry capital expenditures do not increase with industry q as they do before. In that figure, we report the Spearman 
rank correlation between capital expenditures and q for each year in our sample. This correlation is negative in only two years before 1996, but after that it is negative in all but three years.

To better understand the corporate investment pattern after the mid-1990s, it is useful to look at the aggregate level of investment over time. Figure 5 shows that, after 1996, U.S. public firms invest less relative to cash flow. Specifically, net investment tracks aggregate cash flow well until roughly 2000 and after that, a positive gap emerges between cash flow and net investment. (Net investment, defined as in Frank and Goyal (2003), is capital expenditures plus increase in investments plus acquisitions plus other use of funds minus sale of PPE and sale of investments.) As shown in Table 4, this gap shows up differently for the low-funded industries and the high-funded industries. The cash flow of high-funded industries is similar in the two sub-periods, while the cash flow of low-funded industries increases slightly in the second sub-period. For both high and low-funded industries, capital expenditures fall sharply. Consequently, unlike the pre-1997 period when the cash flow of low-funded industries is not enough to fund their capital expenditures, those industries have excess cash flows after the end of 1996. To be more precise, the cash flow of low-funded industries in the year of assignment is $7.4 \%$, but their capital expenditures are only 4.3\%. In other words, these industries could fund all their capital expenditures and would have excess cash flow of $3.1 \%$ of assets. These industries pay dividends of $1.5 \%$ of assets, so that after paying dividends, they still have an excess cash flow of $1.6 \%$.

To further examine the relation between an industry's funding rate, its q, and its cash flow, we estimate regressions using all industry-years. We cluster the standard errors by industry and year and demean all variables by year to control for year fixed effects. We then regress the funding rate on industry q, cash flow measures, and capital expenditure measures. In Panel A of Table 5, we show the estimates for the whole period. We find that industry q is not significant in any of our regressions. In the first regression, we regress the funding rate on industry q, concurrent cash flow, and lagged cash flow. Concurrent cash flow has a significant negative coefficient and lagged cash flow has a significant positive coefficient. Perhaps not surprisingly, when we add concurrent capital expenditures, the coefficient is positive and significant. Lastly, 
to examine whether firms raise funds in anticipation of capital expenditures, we add lead capital expenditures, which have an insignificant coefficient.

Panel B provides estimates for the first sub-period. Industry q is positive and significant. This result is consistent with our quintile analysis. The other coefficients and their significance are consistent with the results of Panel A. However, when we turn to Panel C, q is never significant and the lagged cash flow also becomes insignificant.

The above analysis confirms our puzzle: after 1996, the industries that generate more cash flows and also have higher qs no longer raise more funds from capital markets and invest more than other industries. Surprisingly, the low-funded industries have a higher q after 1996 than the high-funded industries before, since their q in the assignment year is 1.58 versus 1.30 for the high-funded firms before 1997 . Yet, during the assignment year, these low-funded industries have capital expenditures of $4.3 \%$ while the high-funded industries before 1997 have capital expenditures of $11.9 \%$ despite their substantially lower q. An obvious related question is what these firms do with the excess cash. The fact that low-funded industries have a negative funding rate after 1996 provides a clue. To have a negative funding rate, an industry has to buy back equity or reduce its debt. In the next section, we investigate whether low-funded industries reduce their debt or reduce their equity when their funding rate is negative.

A concern with the regressions in Table 5 is that Tobin's q is estimated with error. It could be that error in estimation of Tobin's q changed in the 1990s. Note that concerns about Tobin's q estimation error are attenuated because we use industry $q$ and the earlier analysis employs the median q within the industry funding quintiles. Proceeding this way means that our results are not influenced by extremely high values of q within an industry. Nevertheless, as a further check, we re-estimate the first regression using Erickson, Jiang, and Whited's (2014) higher-order cumulant estimators that account for errors in the measurement of Tobin's q but do not tabulate the results. With this approach, we reach the same conclusions as when we use OLS. To be precise, for the first sub-period, the coefficients on industry q are significantly positive as with OLS, albeit their magnitude is higher. In contrast, for the second sub-period, the coefficients on 
industry q are negative. With OLS, the coefficient on industry q is not significant. With the cumulant estimators, the coefficient on industry q is insignificant when the highest moment is the third or the fourth, but it is significantly negative when the highest moment is the fifth. It is clear that the relation between industry funding rate and q ratio differs between the two sub-periods.

\section{Debt versus equity funding rates}

We have seen that there is a sharp change in the relation between the industry funding rate and industry $\mathrm{q}$ in the middle of the 1990s. Before then, the capital markets funnel funds to the industries with the best growth opportunities. After the middle of the 1990s, it does not appear to work that way. This change is accompanied by a sharp increase in the fraction of industries with negative net funding. Before 1997, $22 \%$ of the industries on average have negative net funding; after, it is $47 \%$ of industries.

Negative funding in debt markets means a reduction in debt, so that for given assets, book leverage falls. However, such a reduction in leverage could result from firms being unable to roll over debt rather than from a decision to reduce debt. Negative funding in equity markets cannot result from constraints in raising equity. Instead, negative funding in equity markets represents voluntary payouts. ${ }^{4}$ Negative funding in equity markets consists of repurchases and the literature emphasizes that the benefit of repurchases over dividends is their flexibility (Jagannathan, Stephens, and Weisbach (2000)). To understand the change in how industries are funded by capital markets, it is important to understand whether the negative net funding is due to debt reduction or to repurchases.

Figure 6 shows the debt and equity funding for the aggregate corporate sector represented by our sample of industries. Until the middle of the 1990s, total external funding, composed of equity and longterm debt, is rather stable, with the exception of decreases in debt funding around recessions. Net equity funding is smaller than net debt funding in almost all years. However, after the middle of the 1990s, debt

\footnotetext{
${ }^{4}$ A concern could be that our approach treats dividends differently from repurchases. Though we do not report the results, our inferences about the correlation between funding and Tobin's q are unchanged if we treat dividends like repurchases.
} 
funding increases sharply and becomes much more volatile. Simultaneously, net equity funding becomes negative after a peak in 2000. During the 2000s, net debt funding and net equity funding are almost mirror images and net corporate funding is negative but small until the last three years of our sample when it turns positive again. Ma (2016) shows that firms buy back equity when debt is cheap, so that firms issue debt to finance buybacks. Such capital structure arbitrage by firms can help explain this negative comovement of equity issuance and debt issuance (alternatively, a positive comovement between equity repurchases and debt issuance).

In Table 6, we show the median equity and debt funding rates for the low and high-funded industries. The table is constructed as follows. Each year, we rank total funding rates and assign industries to quintiles. We then calculate the median equity funding rate for the low and high-funded quintiles. We do the same for debt. Table 6 reveals a dramatic change in net equity funding for the low-funded industries. Before 1997, the average net equity median funding rate for the industries in the lowest quintile of net funding is $-0.4 \%$. After 1996, it is $-2.6 \%$. In some years, the negative net equity funding rate of the low-funded industries is especially large. For instance, in 2006 and 2014, the median net equity funding rate of the low-funded industries is $-5.1 \%$. There is no such evolution for median net debt funding. Before the end of 1996, median net debt funding for the low-funded industries is $-1 \%$. After the end of 1996, it is $-0.7 \%$. In other words, the low-funded industries reduce debt less and equity much more after the end of 1996 compared to before.

The phenomenon of the negative correlation between the funding rate and the industry $\mathrm{q}$ is due to a change in the relationship between equity funding and industry q. This is made clear when we look at correlations separately for equity funding and debt funding in Figure 7.5 The correlation between the equity funding rate and industry q is positive almost every year before 1995, but after the end of 1996, there is only one year where the correlation between equity funding and industry q is positive, namely in 2000 . Every year after 2000, the correlation is negative and in 8 years it exceeds 0.5 in absolute value. In contrast,

\footnotetext{
${ }^{5}$ Our inferences are not materially affected if we use the Peters and Taylor (2016) adjustment of Tobin's q for intangibles. During the period after 1996, taking into account intangibles does not change the sign of the correlation between industry funding rate and q, except for one year (1997).
} 
the correlation between the net debt funding rate and industry $\mathrm{q}$ is almost always positive. Over the whole sample, there are 10 years when it is negative. There is, however, a higher frequency of negative correlations after 1996, as 7 of those negative correlations are after 1996.

Another way to illustrate the role of equity funding in our results is to rank industries by equity funding and to rank them separately by debt funding. We already know that when we rank industries by their total funding rate, high-funded industries have a higher industry q than low-funded industries before 1997 and the opposite holds after. However, as shown in Figure 8, this result is driven by industries that have the lowest equity funding rate. Low-funded industries for long-term debt almost always have a lower industry q than high-funded industries for long-term debt. Turning to equity funding, the low-funded industries have a lower industry q most years until the mid-1990s. After 2000, the q difference between low- and highfunded industries switches sign and a large positive industry q gap develops between these two types of industries.

\section{Can repurchases help explain the puzzle?}

After the middle of the 1990s, the industries that have low funding are industries that repurchase equity and have a high industry q. Before the middle of the 1990s, this is not the case. The magnitude of repurchases changes fairly dramatically in the mid-1990s. Dittmar and Dittmar (2004) point out that 1997 is the first year when the dollar amount of repurchases exceeds the dollar amount of dividends. DeAngelo, DeAngelo, and Skinner (2008) show that repurchases stay above dividends afterwards for their sample period. Important accounting changes help explain the growth in repurchases. First, in 1995, through FASB 123 , the treatment of stock option compensation is clarified in such a way that firms are not required to use the fair value of options granted, which makes granting options more attractive to them. Second, in 1997, through FASB 127, firms are required to report diluted EPS, so that granting options decreases EPS unless 
the firm repurchases shares to offset the dilution. These developments make both option compensation more attractive and repurchases more valuable in managing reported earnings. ${ }^{6}$

Figure 9 shows the evolution of total dollar repurchases for the industries in our sample and compares total dollar repurchases to the excess of cash flow over net investment. The figure shows that dollar repurchases take off in the mid-1990s. Early in the 2000s, cash flow in excess of investment increases sharply, so that cash flow in excess of investment mostly exceeds repurchases. The dotted line in the figure tracks the total of repurchases and changes in cash holdings. After the increase in net cash flow over investment in the early 2000s, the sum of repurchases and changes in cash holdings tracks cash flow in excess of net investment. Cash flow in excess of net investment increases because dollar cash flow increases much more than dollar net investment - from 2000 to 2014, cash flow almost doubles while capital expenditures increase by roughly a quarter.

Another way to look at the relationships among cash flow, investment, and repurchases is to compute the ratio of capital expenditures to operating cash flow for repurchasers and non-repurchasers (not tabulated). For repurchasers as a whole, this ratio is 1.18 during the first sub-period and 0.68 during the second sub-period. In contrast, for non-repurchasers, the ratio is 1.39 in the first sub-period and 1.30 in the second. It follows that repurchasers have an excess of cash flow over capital expenditures in the second sub-period.

We now show that without the equity repurchasers, there is no change in how capital markets allocate funds throughout our sample period. In other words, the reason that the industries with the highest funding rate do not have a higher industry q than the industries with the lowest funding rate is that the low-funded industries have high cash flows but low capital expenditures and they use the resulting excess cash flow to repurchase equity.

\footnotetext{
${ }^{6}$ Bens, Nagar, Skinner, and Wong (2003) analyze the role of repurchases in managing earnings and provide additional references.
} 
We first estimate the correlations between the total funding rate and industry q excluding from each industry firms that repurchase equity for the years in which they repurchase equity. ${ }^{7}$ When we do that, as shown in Table 7, we find that the correlation is positive every year but three. The exceptions are 1973, 1997, and 2013. We next repeat this calculation using the equity funding rate. All observations but two are positive. Finally, we turn to the debt funding rate. For the debt funding rate, eight observations are negative. It follows that the negative relation between industry q and the industry funding rate we observe after 1996 does not hold if we exclude the firms that repurchase equity. The consistently positive relation between industry q and the industry funding rate, without repurchasers, is confirmed in the regression setting as well. As shown in Table 8, the industry $q$ is significantly and positively related to the industry funding rate throughout the entire sample period, provided that repurchasers are excluded from the sample.

Given that there is a positive relation between the funding rate and industry $\mathrm{q}$ when we exclude repurchasers, we expect a positive correlation between the repurchase amount and industry q. We show that correlation in Figure 10. As can be seen in that figure, the correlation is not consistently positive before the middle of the 1990s. After the middle of the 1990s, the correlation is consistently positive and much larger than in any year before. Hence, high q firms repurchase more, which leads them to have a lower funding rate.

It follows from our analysis that the paradox that industry funding is negatively related to industry q in the second sub-period but not the first can be explained by the fact that repurchasers in the second subperiod are high q firms with excess cash flow over investment. Many observers have the view that firms that repurchase at times reduce their investment so that they can repurchase-i.e., repurchases lead firms to under-invest (Lazonick (2014)). Recently, Almeida, Fons, and Kronlund (2016) find support for the view that share repurchases that increase earnings per share are associated with a decrease in investment and they conclude that their evidence suggests that "managers are willing to trade off investments and employment

\footnotetext{
${ }^{7}$ An alternative approach is to compute the funding rate by setting it to zero for repurchasers and including the repurchasers in the estimate of the industry q. The results are similar with this alternative approach.
} 
for stock repurchases that allow them to meet analyst EPS forecasts." We have no basis to reach conclusions about causation with our evidence. Our evidence points to the fact, however, that the industries with negative net funding, which are industries with high repurchases, are industries with a high q, high cash flow, and low capital expenditures after the middle of the 1990s. The resulting excess cash flow enables these industries to repurchase equity on net as they are not using all of that cash flow to invest.

Our evidence shows that the allocation of capital seems more functionally efficient when repurchasers are omitted. However, removing share repurchasing firms from the sample does not help with the convergence hypothesis, since the exclusion of repurchasers provides results supportive of the convergence hypothesis in the second sub-period, but not in the first. Also, removing share repurchasers from the sample does not help with the correlation of capex with Tobin's q. Though we do not report the results in a figure, the correlation of Tobin's q and capex after 1996 is not materially different when we remove the repurchasers. Further, when we estimate a regression of capex on industry q and concurrent cash flow (not tabulated), the coefficient on $\mathrm{q}$ is significantly negative in the second sub-period with all firms and insignificantly negative when we remove repurchasers.

\section{Conclusion}

In this paper, we show that there is a dramatic change in how capital markets allocate capital across industries in the mid-1990s in the U.S. Before the mid-1990s, industries that attract the most capital per dollar of assets are industries with better growth opportunities (measured by the industry's Tobin's q) than the industries that attract the least capital per dollar of assets. If capital markets' price signals are correct and capital markets are functionally efficient, industries that can make the best use of capital have a higher industry q than those that cannot make such a use. Consequently, before the mid-1990s, capital markets

appear to be functionally efficient. After the mid-1990s, it is no longer true that capital markets appear to be functionally efficient if functional efficiency means that capital flows more to industries with a higher 
Tobin's q. Specifically, after the mid-1990s, there is a negative (Spearman rank) correlation between industry funding flows and industry qs.

The negative correlation between industry funding flows and industry qs after the middle of the 1990s does not exist if we remove the firms that repurchase shares from the sample. It is striking that repurchases are large in industries that have a high q. We would expect high q industries to invest more and hence require more funding. This is not the case after the middle of the 1990s. Industries that have the lowest funding rates have high qs but they invest less than the industries with the highest funding rates that have lower qs. The lowest-funded industries also invest less than their own cash flow, so that they have funds to repurchase equity. The q-theory of investment fails completely after the mid-1990s at the industry level, while it does not before.

Whether capital flows more towards industries with the best growth opportunities depends both on the efficiency of capital markets and on the policies of firms. If firms do not want to raise funds, more efficient capital markets will not make these firms want to raise funds. Hence, the outcome we document depends both on how capital markets allocate resources and on the decision of firms. Of course, things are even more complicated because capital markets set incentives for firms. For instance, if capital markets penalize firms for some types of investments, they may choose not to invest and repurchase their shares instead. Our study cannot establish causality. It only shows how the allocation of capital has changed dramatically and that repurchases play a critical role in this change.

There are several possible explanations for our results that future research should investigate. It is important to note, however, that any explanation has to explain why there was a change in the 1990s that has persisted to now. To start with, there has been growing concern about short-termism incentives for managers (see, for instance, Foroohar (2016) for a discussion of this concern). It is possible that incentives for managers changed in some high q industries so that they do not want to invest to such an extent that they have to raise external funds. They are reluctant to do so because they believe that their share price does not benefit when they do so. They can have other reasons not to invest more. In particular, they may be 
leery to access outside markets as such access involves monitoring. Alternatively, there could be a decrease in competition so that high qs may reflect rents so that investing more for such firms could lead to lower prices and lower profits. It is also possible that firms have high qs because of repurchases, so that the high qs may not indicate to managers that they have valuable investment opportunities. Finally, since the 1990s, some industries may have high qs because of past investments that have high future cash flows, but firms in these industries may not be able to find investments that have similar future cash flows.

It is also important to note that after the mid-1990s, R\&D expenditures and investments in other intangibles have been especially important for U.S. firms (see Kahle and Stulz (2016)). As a result, firms correspond less and less to the simplistic model of manufacturing firms that invest mostly in capital expenditures and experience decreasing returns to scale as they invest more, leading their q to fall. Related to this concern is the fact that it is well-known that $\mathrm{q}$ is measured with error. We have taken many steps to reduce the importance of measurement error, but we can't exclude that such error may affect some of our results. It seems unlikely, however, that measurement error changed drastically in the second half of the 1990s, which is what would be required to explain our results. 


\section{References}

Almeida, H., V. Fos, and M. Kronlund, 2016. The real effects of share repurchases. Journal of Financial Economics 119, 168-185.

Baker, M., and J. Wurgler, 2013. Behavioral corporate finance: An updated survey. Handbook of the Economics of Finance, G. Constantinides, M. Harris, and R. Stulz, editors, Elsevier, 357-424.

Barclay, M., and C. Smith, 1995. The maturity structure of corporate debt. Journal of Finance 50(2), 609631.

Bens, D.A., V. Nagar, D.J. Skinner, and M.H.F. Wong. 2003. Employee stock options, EPS dilution, and stock repurchases. Journal of Accounting and Economics 36, 51-90.

Covas, F., and W.J. den Haan, 2011. The cyclical behavior of debt and equity finance. American Economic Review 101, 877-899.

DeAngelo, H., L. DeAngelo, and D.J. Skinner, 2008. Corporate payout policy. Foundations and Trends in Finance 3, 95-287.

Dittmar, A.K., and R.F. Dittmar, 2004. Stock repurchase waves: An explanation of the trends in aggregate payout policy. Working paper. University of Michigan.

Doidge, C., G.A. Karolyi, and R.M. Stulz, 2016. The U.S. listing gap. Journal of Financial Economics, forthcoming.

Erickson, T., C. Jiang, and T. Whited, 2014. Minimum distance estimation of the errors-in-variables model using linear cumulant equations. Journal of Econometrics 1983, 211-221.

Fama, E.F. and K.R. French, 1997. Industry costs of equity. Journal of Financial Economics 43, pp.153193.

Fama, Eugene F., and Kenneth R. French, 2005. Financing decisions: Who issues stock? Journal of Financial Economics 76, 549-582.

Foroohar, R., 2016. Makers and takers: The rise of finance and the fall of American business. Crown Business.

Frank, M.Z., and V.K. Goyal, 2003. Testing the pecking order theory of capital structure. Journal of Financial Economics 67, 217-248.

Guetiérrez, G., and T. Philippon, 2016, Investment-less growth: An empirical investigation, unpublished working paper.

Hoberg, G., and G. Phillips, 2010. Real and financial industry booms and busts. Journal of Finance 65(1), 45-86.

Jagannathan M., C.P. Stephens, and M.S. Weisbach, 2000. Financial flexibility and the choice between dividends and stock repurchases. Journal of Financial Economics 57, 355-384. 
Jermann, U., and V. Quadrini, 2012, Macroeconomic effects of financial shocks, American Economic Review 102, 238-271.

Kahle, K.M., and R.M. Stulz, 2016. Is the American public corporation in trouble? Unpublished working paper, National Bureau of Economic Research.

Lazonick, W., 2014. Profits without prosperity. Harvard Business Review 92(9), 46-55.

Levine, R., 1997. Financial development and economic growth: Views and agenda. Journal of Economic Literature, 35, pp.688-726.

Ma, Y., 2016. Non-financial firms as cross-market arbitrageurs. Unpublished working paper. Harvard University.

Ozbas, O., and D. Scharfstein, 2010. Evidence on the dark side of internal capital markets. Review of Financial Studies 23(2), 581-59.

Rajan, R.G. and L. Zingales, 1998. Financial dependence and growth. American Economic Review 88(3), pp.559-586.

Shleifer, A., and R. Vishny, 2003. Stock market driven acquisitions. Journal of Financial Economics 70, 295-312.

Stein, J., 1996. Rational capital budgeting in an irrational world. Journal of Business, 69(4), pp.429-455.

Tobin, J., 1984. On the efficiency of the financial system. Lloyd's Bank Review 153(July), 1-15.

Wurgler, J., 2000. Financial markets and the allocation of capital. Journal of financial economics, 58(1), pp.187-214. 


\section{Appendix}

Variable definitions

\begin{tabular}{|c|c|}
\hline variable & definition \\
\hline funding rate (total) & $\begin{array}{l}\text { (SSTK - PRSTKC + DLTIS - DLTR)/AT, where AT is lagged by one year. If any of the } \\
\text { four variables in the numerator is missing, then we treat it as zero. }\end{array}$ \\
\hline funding rate (equity) & $\begin{array}{l}\text { (SSTK - PRSTKC)/AT, where AT is lagged by one year. If any of the two variables in the } \\
\text { numerator is missing, then we treat it as zero. }\end{array}$ \\
\hline funding rate (debt) & $\begin{array}{l}\text { (DLTIS - DLTR)/AT, where AT is lagged by one year. If any of the two variables in the } \\
\text { numerator is missing, then we treat it as zero. }\end{array}$ \\
\hline q & $\begin{array}{l}(\mathrm{AT}-(\mathrm{CEQ}+\mathrm{TXDITC})+(\mathrm{CRSP} \text { per-share price*number of shares outstanding })) / \mathrm{AT} \text {, } \\
\text { all at the end of the previous year }\end{array}$ \\
\hline capital expenditure & CAPX /AT, where AT is lagged by one year \\
\hline change in \# of firms & percentage change in the number of firms in a given industry \\
\hline cash dividend & $(\mathrm{DVC}+\mathrm{DVP}) / \mathrm{AT}$, where AT is lagged by one year \\
\hline change in asset & percentage change in AT of a given industry \\
\hline operating income & OIBDP/AT, where AT is lagged by one year \\
\hline cash flows & (OIBDP - XINT - TXT - DVC)/AT, all at the end of previous year \\
\hline net investment & $\begin{array}{l}\mathrm{CAPX}+\mathrm{IVCH}+\mathrm{AQC}+\mathrm{FUSEO}-\mathrm{SPPE}-\mathrm{SIV}(\text { for reporting format codes } 1 \text { to } 3 \text { ) } \\
\mathrm{CAPX}+\mathrm{IVCH}+\mathrm{AQC}-\mathrm{SPPE}-\mathrm{SIV}-\mathrm{IVSTCH}-\mathrm{IVACO}(\text { for reporting format code } 7)\end{array}$ \\
\hline
\end{tabular}




\section{Table 1. Industry funding rate}

U.S. firms from 1971 to 2014 with a positive value for total assets in Compustat (in February 2016) are assigned to one of the Fama and French's 48 industries or dropped if such an assignment is not possible. Regulated industries, as identified by Barclay and Smith (1995), are excluded from the sample. An industry group is required to have at least 10 firms in a given year. Equity funding during a year is computed as the sale of common stock and preferred stock minus the purchase of common and preferred stock. Debt funding is the issuance of long-term debt minus the reduction of long-term debt. The funding rate of an industry is the sum of all equity and debt funds raised by the industry's firms during the year, divided by the sum of those firms' total assets at the start of the year. An industry with a negative funding rate is called a "rationed" industry. 


\begin{tabular}{|c|c|c|c|c|c|c|c|c|c|c|c|}
\hline (1) & (2) & (3) & (4) & (5) & (6) & (7) & (8) & (9) & (10) & (11) & (12) \\
\hline \multirow{2}{*}{ year } & $\#$ of & \# of & \multicolumn{7}{|c|}{ summary statistics of industry funding rate } & \multirow{2}{*}{$\begin{array}{r}\text { \# of } \\
\text {-industries } \\
\text { rationed }\end{array}$} & \multirow{2}{*}{$\begin{array}{l}\% \text { of } \\
\text { industries } \\
\text { rationed }\end{array}$} \\
\hline & companies & industries & mean & std & $\min$ & q1 & median & q3 & $\max$ & & \\
\hline all years & 205,622 & 1,736 & $1.8 \%$ & $5.3 \%$ & $-12.1 \%$ & $-0.6 \%$ & $1.2 \%$ & $3.4 \%$ & $117.7 \%$ & 566 & $32.6 \%$ \\
\hline 1971 & 1,809 & 37 & $4.1 \%$ & $6.2 \%$ & $-2.8 \%$ & $1.7 \%$ & $2.8 \%$ & $4.0 \%$ & $38.1 \%$ & 2 & $5.4 \%$ \\
\hline 1972 & 2,375 & 39 & $3.0 \%$ & $3.3 \%$ & $-0.8 \%$ & $1.0 \%$ & $2.2 \%$ & $3.2 \%$ & $18.4 \%$ & 2 & $5.1 \%$ \\
\hline 1973 & 2,744 & 39 & $2.2 \%$ & $2.5 \%$ & $-2.2 \%$ & $0.7 \%$ & $1.5 \%$ & $3.4 \%$ & $8.6 \%$ & 5 & $12.8 \%$ \\
\hline 1974 & 2,949 & 39 & $2.8 \%$ & $2.6 \%$ & $-2.5 \%$ & $1.2 \%$ & $2.7 \%$ & $4.3 \%$ & $9.8 \%$ & 4 & $10.3 \%$ \\
\hline 1975 & 2,923 & 40 & $1.5 \%$ & $2.9 \%$ & $-3.9 \%$ & $-0.9 \%$ & $1.6 \%$ & $3.2 \%$ & $10.3 \%$ & 13 & $32.5 \%$ \\
\hline 1976 & 2,907 & 40 & $0.9 \%$ & $2.1 \%$ & $-3.8 \%$ & $0.0 \%$ & $0.6 \%$ & $1.7 \%$ & $8.8 \%$ & 10 & $25.0 \%$ \\
\hline 1977 & 2,857 & 39 & $2.2 \%$ & $2.4 \%$ & $-3.2 \%$ & $0.5 \%$ & $1.9 \%$ & $3.2 \%$ & $11.3 \%$ & 6 & $15.4 \%$ \\
\hline 1978 & 2,841 & 39 & $3.0 \%$ & $4.4 \%$ & $-0.6 \%$ & $0.7 \%$ & $2.2 \%$ & $3.8 \%$ & $26.3 \%$ & 5 & $12.8 \%$ \\
\hline 1979 & 2,894 & 38 & $3.6 \%$ & $3.2 \%$ & $-0.1 \%$ & $1.5 \%$ & $2.8 \%$ & $4.6 \%$ & $14.0 \%$ & 1 & $2.6 \%$ \\
\hline 1980 & 2,975 & 38 & $4.1 \%$ & $5.7 \%$ & $-0.1 \%$ & $1.3 \%$ & $2.9 \%$ & $4.2 \%$ & $34.2 \%$ & 1 & $2.6 \%$ \\
\hline 1981 & 3,262 & 38 & $3.7 \%$ & $4.9 \%$ & $-0.6 \%$ & $0.7 \%$ & $2.9 \%$ & $3.9 \%$ & $20.8 \%$ & 3 & $7.9 \%$ \\
\hline 1982 & 3,330 & 38 & $3.0 \%$ & $4.6 \%$ & $-0.8 \%$ & $0.5 \%$ & $1.9 \%$ & $3.7 \%$ & $25.9 \%$ & 7 & $18.4 \%$ \\
\hline 1983 & 3,717 & 38 & $2.9 \%$ & $5.4 \%$ & $-2.1 \%$ & $-0.2 \%$ & $1.2 \%$ & $4.2 \%$ & $25.3 \%$ & 13 & $34.2 \%$ \\
\hline 1984 & 3,934 & 38 & $1.7 \%$ & $3.8 \%$ & $-4.6 \%$ & $-0.8 \%$ & $1.2 \%$ & $3.0 \%$ & $13.0 \%$ & 16 & $42.1 \%$ \\
\hline 1985 & 4,049 & 39 & $3.3 \%$ & $5.0 \%$ & $-6.2 \%$ & $1.0 \%$ & $2.1 \%$ & $5.6 \%$ & $20.2 \%$ & 6 & $15.4 \%$ \\
\hline 1986 & 4,276 & 39 & $4.9 \%$ & $5.9 \%$ & $-2.9 \%$ & $1.2 \%$ & $3.7 \%$ & $6.5 \%$ & $26.7 \%$ & 6 & $15.4 \%$ \\
\hline 1987 & 5,784 & 40 & $4.0 \%$ & $10.8 \%$ & $-10.6 \%$ & $-1.8 \%$ & $1.6 \%$ & $5.5 \%$ & $54.3 \%$ & 16 & $40.0 \%$ \\
\hline 1988 & 5,579 & 39 & $0.7 \%$ & $4.5 \%$ & $-12.1 \%$ & $-2.5 \%$ & $1.0 \%$ & $3.1 \%$ & $11.1 \%$ & 15 & $38.5 \%$ \\
\hline 1989 & 5,439 & 39 & $1.6 \%$ & $4.4 \%$ & $-9.2 \%$ & $-0.7 \%$ & $1.0 \%$ & $3.1 \%$ & $17.4 \%$ & 14 & $35.9 \%$ \\
\hline 1990 & 5,439 & 39 & $0.3 \%$ & $2.7 \%$ & $-9.4 \%$ & $-0.7 \%$ & $0.7 \%$ & $2.0 \%$ & $5.2 \%$ & 15 & $38.5 \%$ \\
\hline 1991 & 5,525 & 39 & $1.4 \%$ & $3.3 \%$ & $-3.8 \%$ & $-0.5 \%$ & $0.6 \%$ & $2.7 \%$ & $16.1 \%$ & 12 & $30.8 \%$ \\
\hline 1992 & 5,831 & 40 & $1.4 \%$ & $3.3 \%$ & $-8.8 \%$ & $-0.1 \%$ & $1.2 \%$ & $2.4 \%$ & $12.5 \%$ & 13 & $32.5 \%$ \\
\hline 1993 & 6,121 & 40 & $1.4 \%$ & $2.8 \%$ & $-6.2 \%$ & $-0.1 \%$ & $1.2 \%$ & $3.3 \%$ & $8.8 \%$ & 11 & $27.5 \%$ \\
\hline 1994 & 6,419 & 39 & $1.9 \%$ & $4.2 \%$ & $-5.7 \%$ & $-0.5 \%$ & $1.3 \%$ & $2.9 \%$ & $17.0 \%$ & 12 & $30.8 \%$ \\
\hline 1995 & 7,128 & 41 & $2.8 \%$ & $4.3 \%$ & $-8.0 \%$ & $0.2 \%$ & $2.7 \%$ & $4.9 \%$ & $11.4 \%$ & 8 & $19.5 \%$ \\
\hline 1996 & 7,277 & 41 & $3.6 \%$ & $5.7 \%$ & $-5.9 \%$ & $0.5 \%$ & $1.8 \%$ & $7.2 \%$ & $22.0 \%$ & 10 & $24.4 \%$ \\
\hline 1997 & 7,078 & 40 & $3.3 \%$ & $6.1 \%$ & $-8.4 \%$ & $-0.4 \%$ & $1.6 \%$ & $6.1 \%$ & $25.2 \%$ & 11 & $27.5 \%$ \\
\hline 1998 & 7,170 & 40 & $3.2 \%$ & $4.1 \%$ & $-5.1 \%$ & $0.8 \%$ & $2.4 \%$ & $5.3 \%$ & $14.7 \%$ & 6 & $15.0 \%$ \\
\hline 1999 & 7,083 & 40 & $3.0 \%$ & $3.7 \%$ & $-4.4 \%$ & $0.5 \%$ & $2.6 \%$ & $4.4 \%$ & $11.5 \%$ & 6 & $15.0 \%$ \\
\hline 2000 & 6,750 & 40 & $2.1 \%$ & $4.7 \%$ & $-6.1 \%$ & $-1.2 \%$ & $1.0 \%$ & $5.2 \%$ & $17.9 \%$ & 17 & $42.5 \%$ \\
\hline 2001 & 6,262 & 40 & $1.4 \%$ & $3.4 \%$ & $-7.2 \%$ & $-0.4 \%$ & $1.0 \%$ & $4.2 \%$ & $7.9 \%$ & 13 & $32.5 \%$ \\
\hline 2002 & 5,865 & 39 & $-0.3 \%$ & $2.9 \%$ & $-9.6 \%$ & $-2.3 \%$ & $-0.1 \%$ & $1.3 \%$ & $5.6 \%$ & 20 & $51.3 \%$ \\
\hline 2003 & 5,571 & 41 & $0.5 \%$ & $3.4 \%$ & $-5.0 \%$ & $-1.7 \%$ & $0.0 \%$ & $1.4 \%$ & $9.2 \%$ & 20 & $48.8 \%$ \\
\hline 2004 & 5,365 & 41 & $0.1 \%$ & $4.1 \%$ & $-6.0 \%$ & $-2.5 \%$ & $-0.5 \%$ & $1.2 \%$ & $13.3 \%$ & 24 & $58.5 \%$ \\
\hline 2005 & 5,139 & 41 & $-0.6 \%$ & $4.0 \%$ & $-7.5 \%$ & $-2.7 \%$ & $-1.1 \%$ & $0.9 \%$ & $15.7 \%$ & 25 & $61.0 \%$ \\
\hline 2006 & 4,883 & 41 & $-0.1 \%$ & $3.5 \%$ & $-5.7 \%$ & $-2.6 \%$ & $-0.6 \%$ & $1.9 \%$ & $10.9 \%$ & 25 & $61.0 \%$ \\
\hline 2007 & 4,646 & 41 & $2.6 \%$ & $19.0 \%$ & $-10.2 \%$ & $-3.2 \%$ & $-0.6 \%$ & $2.2 \%$ & $117.7 \%$ & 23 & $56.1 \%$ \\
\hline 2008 & 4,398 & 40 & $-0.1 \%$ & $4.1 \%$ & $-9.7 \%$ & $-2.5 \%$ & $-0.5 \%$ & $2.3 \%$ & $15.6 \%$ & 23 & $57.5 \%$ \\
\hline 2009 & 4,267 & 40 & $-0.1 \%$ & $3.6 \%$ & $-4.7 \%$ & $-2.7 \%$ & $-1.1 \%$ & $1.4 \%$ & $14.4 \%$ & 24 & $60.0 \%$ \\
\hline 2010 & 4,200 & 40 & $-0.3 \%$ & $3.8 \%$ & $-7.0 \%$ & $-2.4 \%$ & $-1.0 \%$ & $1.1 \%$ & $13.5 \%$ & 24 & $60.0 \%$ \\
\hline 2011 & 4,163 & 39 & $-0.2 \%$ & $4.3 \%$ & $-6.2 \%$ & $-1.8 \%$ & $-1.1 \%$ & $0.8 \%$ & $22.0 \%$ & 27 & $69.2 \%$ \\
\hline 2012 & 4,245 & 40 & $0.7 \%$ & $2.6 \%$ & $-5.8 \%$ & $-0.9 \%$ & $0.3 \%$ & $2.4 \%$ & $6.2 \%$ & 17 & $42.5 \%$ \\
\hline 2013 & 4,246 & 40 & $0.5 \%$ & $2.9 \%$ & $-3.9 \%$ & $-2.1 \%$ & $0.3 \%$ & $2.8 \%$ & $8.6 \%$ & 19 & $47.5 \%$ \\
\hline 2014 & 3,907 & 38 & $0.1 \%$ & $3.2 \%$ & $-8.2 \%$ & $-2.2 \%$ & $0.6 \%$ & $2.2 \%$ & $6.5 \%$ & 16 & $42.1 \%$ \\
\hline
\end{tabular}


Table 2. Funding patterns by industry from 1971 to 2014

The industries are the Fama-French 48 industries. Financials and utilities are excluded from the sample, as well as the regulated industries, as identified by Barclay and Smith (1995). The funding rate of an industry is the sum of all equity and debt funds raised by the industry's firms during the year, divided by the sum of those firms' total assets at the start of the year. Industries that are "rationed" or "funded" are, respectively, those that have a negative or positive funding rate. Each year, sample industries are also sorted into quintiles based on their total funding rates. "Low-funded" and "high-funded" quintiles are, respectively, the group of industries that are least and most funded during the year.

\begin{tabular}{|c|c|c|c|c|c|c|}
\hline $\begin{array}{l}\text { industry } \\
\text { code }\end{array}$ & industry description & $\begin{array}{l}\text { \# of years } \\
\text { in sample }\end{array}$ & $\begin{array}{r}\text { \# of years } \\
\text { rationed }\end{array}$ & $\begin{array}{r}\text { \# of years } \\
\text { funded }\end{array}$ & $\begin{array}{r}\text { \# of years in } \\
\text { "low-funded" } \\
\text { quintile }\end{array}$ & $\begin{array}{r}\text { \# of years in } \\
\text { "high-funded" } \\
\text { quintile }\end{array}$ \\
\hline 1 & Agriculture & 43 & 15 & 28 & 11 & 10 \\
\hline 2 & Food Products & 44 & 18 & 26 & 12 & 3 \\
\hline 3 & Candy \& Soda & 38 & 15 & 23 & 5 & 6 \\
\hline 4 & Beer \& Liquor & 42 & 24 & 18 & 22 & 4 \\
\hline 5 & Tobacco Products & 11 & 2 & 9 & 2 & 1 \\
\hline 6 & Recreation & 44 & 15 & 29 & 8 & 7 \\
\hline 7 & Entertainment & 44 & 5 & 39 & 3 & 20 \\
\hline 8 & Printing and Publishing & 44 & 19 & 25 & 10 & 4 \\
\hline 9 & Consumer Goods & 44 & 23 & 21 & 13 & 1 \\
\hline 10 & Apparel & 44 & 22 & 22 & 15 & 0 \\
\hline 11 & Healthcare & 44 & 10 & 34 & 5 & 24 \\
\hline 12 & Medical Equipment & 44 & 9 & 35 & 0 & 12 \\
\hline 13 & Pharmaceutical Products & 44 & 14 & 30 & 8 & 8 \\
\hline 14 & Chemicals & 44 & 16 & 28 & 11 & 7 \\
\hline 15 & Rubber and Plastic Products & 44 & 16 & 28 & 11 & 8 \\
\hline 16 & Textiles & 43 & 21 & 22 & 13 & 3 \\
\hline 17 & Construction Materials & 44 & 14 & 30 & 3 & 4 \\
\hline 18 & Construction & 44 & 14 & 30 & 10 & 19 \\
\hline 19 & Steel Works Etc & 44 & 10 & 34 & 9 & 8 \\
\hline 20 & Fabricated Products & 40 & 14 & 26 & 10 & 11 \\
\hline 21 & Machinery & 44 & 11 & 33 & 6 & 7 \\
\hline 22 & Electrical Equipment & 44 & 13 & 31 & 11 & 3 \\
\hline 23 & Automobiles and Trucks & 44 & 9 & 35 & 7 & 6 \\
\hline 24 & Aircraft & 44 & 23 & 21 & 16 & 4 \\
\hline 25 & Shipbuilding, Railroad Equipment & 31 & 13 & 18 & 8 & 6 \\
\hline 26 & Defense & 26 & 20 & 6 & 17 & 2 \\
\hline 27 & Precious Metals & 36 & 8 & 28 & 7 & 22 \\
\hline 28 & Non-Metallic and Industrial Metal Mining & 44 & 8 & 36 & 5 & 16 \\
\hline 29 & Coal & 18 & 3 & 15 & 3 & 9 \\
\hline 30 & Petroleum and Natural Gas & 44 & 14 & 30 & 4 & 4 \\
\hline 32 & Communication & 44 & 8 & 36 & 0 & 15 \\
\hline 33 & Personal Services & 44 & 15 & 29 & 3 & 17 \\
\hline 34 & Business Services & 44 & 12 & 32 & 4 & 17 \\
\hline 35 & Computers & 44 & 18 & 26 & 8 & 2 \\
\hline 36 & Electronic Equipment & 44 & 12 & 32 & 4 & 8 \\
\hline 37 & Measuring and Control Equipment & 44 & 6 & 38 & 4 & 5 \\
\hline 38 & Business Supplies & 44 & 14 & 30 & 10 & 8 \\
\hline 39 & Shipping Containers & 44 & 13 & 31 & 8 & 8 \\
\hline 40 & Transportation & 44 & 13 & 31 & 6 & 6 \\
\hline 41 & Wholesale & 44 & 6 & 38 & 0 & 5 \\
\hline 42 & Retail & 44 & 15 & 29 & 6 & 1 \\
\hline 43 & Restaraunts, Hotels, Motels & 44 & 16 & 28 & 12 & 13 \\
\hline
\end{tabular}


Table 3. Median industry q of bottom and top funding quintiles from 1971 to 2014

The industries are the Fama-French 48 industries. The funding rate of an industry is the sum of all equity and debt funds raised by the industry's firms during the year, divided by the sum of those firms' total assets at the start of the year. The industry q is the ratio of market value of assets to book value of assets, all at the end of the previous year. Within an industry, each variable is summed across companies and then the ratio is computed for the industry. 


\begin{tabular}{|c|c|c|c|c|c|}
\hline \multirow[b]{2}{*}{ year } & \multicolumn{5}{|c|}{ median industry q for industry funding quintiles } \\
\hline & $\begin{array}{l}\text { "low-funded" } \\
\text { quintile }\end{array}$ & $\begin{array}{l}\text { "high-funded" } \\
\text { quintile }\end{array}$ & $\begin{array}{c}\text { difference } \\
\text { ("low" - "high") }\end{array}$ & $\begin{array}{c}\text { p-val for } \\
\text { positive } \\
\text { difference (1- } \\
\text { sided Wilcoxon) }\end{array}$ & $\begin{array}{c}\text { p-val for } \\
\text { nonzero } \\
\text { difference (2- } \\
\text { sided Wilcoxon) }\end{array}$ \\
\hline 1971 & 1.01 & 1.19 & -0.17 & . & $(0.371)$ \\
\hline 1972 & 1.11 & 1.33 & -0.22 & . & $(0.325)$ \\
\hline 1973 & 1.24 & 1.30 & -0.05 & . & $(0.524)$ \\
\hline 1974 & 0.93 & 1.25 & -0.32 & . & $(0.056)$ \\
\hline 1975 & 0.92 & 0.89 & 0.02 & $(0.282)$ & $(0.564)$ \\
\hline 1976 & 0.92 & 1.07 & -0.15 & . & $(0.270)$ \\
\hline 1977 & 1.13 & 1.12 & 0.01 & $(0.477)$ & $(0.954)$ \\
\hline 1978 & 1.00 & 1.06 & -0.07 & . & $(0.452)$ \\
\hline 1979 & 0.86 & 0.93 & -0.07 & . & $(0.125)$ \\
\hline 1980 & 1.03 & 1.07 & -0.04 & . & (0.609) \\
\hline 1981 & 1.02 & 1.35 & -0.32 & . & $(0.055)$ \\
\hline 1982 & 0.98 & 1.34 & -0.36 & . & $(0.074)$ \\
\hline 1983 & 1.00 & 1.49 & -0.49 & . & $(0.015)$ \\
\hline 1984 & 1.19 & 1.48 & -0.29 & . & $(0.125)$ \\
\hline 1985 & 1.10 & 1.53 & -0.43 & . & $(0.013)$ \\
\hline 1986 & 1.13 & 1.54 & -0.40 & . & $(0.325)$ \\
\hline 1987 & 1.23 & 1.43 & -0.20 & . & $(0.189)$ \\
\hline 1988 & 1.15 & 1.14 & 0.00 & $(0.431)$ & $(0.862)$ \\
\hline 1989 & 0.93 & 1.28 & -0.36 & . & $(0.452)$ \\
\hline 1990 & 1.22 & 1.19 & 0.02 & $(0.301)$ & $(0.603)$ \\
\hline 1991 & 1.05 & 1.18 & -0.13 & . & $(0.524)$ \\
\hline 1992 & 1.12 & 1.41 & -0.29 & . & $(0.189)$ \\
\hline 1993 & 1.15 & 1.35 & -0.20 & . & $(0.372)$ \\
\hline 1994 & 1.21 & 1.52 & -0.31 & . & $(0.224)$ \\
\hline 1995 & 1.43 & 1.37 & 0.05 & $(0.500)$ & $(1.000)$ \\
\hline 1996 & 1.42 & 1.43 & -0.01 & . & $(1.000)$ \\
\hline 1997 & 1.59 & 1.23 & 0.36 & $(0.026)$ & $(0.052)$ \\
\hline 1998 & 1.68 & 1.36 & 0.32 & $(0.135)$ & $(0.270)$ \\
\hline 1999 & 1.77 & 1.27 & 0.49 & $(0.064)$ & $(0.128)$ \\
\hline 2000 & 1.32 & 1.62 & -0.30 & . & $(0.128)$ \\
\hline 2001 & 1.11 & 1.43 & -0.32 & . & $(0.431)$ \\
\hline 2002 & 1.23 & 1.33 & -0.10 & . & $(0.603)$ \\
\hline 2003 & 1.61 & 1.14 & 0.47 & $(0.002)$ & $(0.004)$ \\
\hline 2004 & 1.71 & 1.32 & 0.39 & $(0.095)$ & $(0.189)$ \\
\hline 2005 & 1.67 & 1.36 & 0.30 & $(0.004)$ & $(0.007)$ \\
\hline 2006 & 1.82 & 1.32 & 0.50 & $(0.052)$ & (0.104) \\
\hline 2007 & 1.87 & 1.60 & 0.27 & $(0.318)$ & $(0.637)$ \\
\hline 2008 & 1.99 & 1.49 & 0.50 & $(0.016)$ & $(0.031)$ \\
\hline 2009 & 1.19 & 1.38 & -0.19 & . & $(0.495)$ \\
\hline 2010 & 1.56 & 1.40 & 0.16 & $(0.318)$ & $(0.637)$ \\
\hline 2011 & 1.79 & 1.69 & 0.10 & $(0.431)$ & $(0.862)$ \\
\hline 2012 & 1.59 & 1.28 & 0.31 & $(0.215)$ & $(0.431)$ \\
\hline 2013 & 1.72 & 1.22 & 0.50 & $(0.003)$ & $(0.005)$ \\
\hline 2014 & 2.13 & 1.23 & 0.90 & $(0.001)$ & $(0.002)$ \\
\hline
\end{tabular}




\section{Table 4. 11-year event window}

The industries are the Fama-French 48 industries. The funding rate of an industry is the sum of all equity and debt funds raised by the industry's firms during the year, divided by the sum of those firms' total assets at the start of the year. The industry $q$ is the ratio of market value of assets to book value of assets, all at the end of the previous year. Within an industry, each characteristic is summed across companies and then the ratio is computed for the industry. Each year we compute the median value of a given characteristic in the top (i.e., "high-funded") or the bottom (i.e., "low-funded") funding quintile, and also compute the median value of the characteristic for the preceding and subsequent five years. Year 0 is the assignment year. Assignment years are from 1976 to 2009 to allow for five years before and after assignment years. We compute the average for each of those 11 median values for the period considered and test the difference in mean between high-funded and low-funded industry quintiles ("p-val: mean diff"). We also report the tests for the difference in median between the two quintiles ("p-val: median diff"). Change in \# of firms is the percentage change in the number of firms during year t. Variables normalized by total assets of the industry. 
Panel A. 11-year event window for the $1^{\text {st }}$ sub-period (1976-1996 funding years)

\begin{tabular}{|c|c|c|c|c|c|c|c|c|c|c|c|c|c|c|c|}
\hline $\begin{array}{l}\text { year } \\
\text { relative } \\
\text { to } \\
\text { funding }\end{array}$ & $\begin{array}{l}\text { "low- } \\
\text { funded" } \\
\text { quintile }\end{array}$ & (p-val) & $\begin{array}{l}\text { "high- } \\
\text { funded" } \\
\text { quintile }\end{array}$ & (p-val) & $\begin{array}{l}\text { "low" } \\
\text { minus } \\
\text { "high" }\end{array}$ & $\begin{array}{r}\text { (p-val: } \\
\text { mean } \\
\text { diff) }\end{array}$ & $\begin{array}{r}(\mathrm{p}-\mathrm{val}: \\
\text { median } \\
\text { diff })\end{array}$ & $\begin{array}{c}\text { year } \\
\text { relative } \\
\text { to } \\
\text { funding }\end{array}$ & $\begin{array}{l}\text { "low- } \\
\text { funded" } \\
\text { quintile }\end{array}$ & (p-val) & $\begin{array}{l}\text { "high- } \\
\text { funded" } \\
\text { quintile }\end{array}$ & (p-val) & $\begin{array}{l}\text { "low" } \\
\text { minus } \\
\text { "high" }\end{array}$ & $\begin{array}{r}\text { (p-val: } \\
\text { mean } \\
\text { diff) }\end{array}$ & $\begin{array}{r}\text { (p-val: } \\
\text { median } \\
\text { diff) }\end{array}$ \\
\hline \multicolumn{8}{|c|}{ total funding rate } & \multicolumn{8}{|l|}{ q ratio } \\
\hline-5 & $1.6 \%$ & $(0.01)$ & $3.0 \%$ & $(0.00)$ & $-1.4 \%$ & $(0.029)$ & $(0.005)$ & -5 & 1.13 & $(0.00)$ & 1.23 & $(0.00)$ & -0.10 & $(0.116)$ & $(0.097)$ \\
\hline-4 & $1.3 \%$ & $(0.00)$ & $3.1 \%$ & $(0.00)$ & $-1.8 \%$ & $(0.002)$ & $(0.002)$ & -4 & 1.15 & $(0.00)$ & 1.19 & $(0.00)$ & -0.04 & $(0.468)$ & $(0.247)$ \\
\hline-3 & $1.0 \%$ & $(0.00)$ & $3.0 \%$ & $(0.00)$ & $-2.1 \%$ & $<.0001$ & $(0.000)$ & -3 & 1.11 & $(0.00)$ & 1.22 & $(0.00)$ & -0.11 & $(0.027)$ & $(0.033)$ \\
\hline-2 & $0.9 \%$ & $(0.00)$ & $3.5 \%$ & $(0.00)$ & $-2.6 \%$ & $<.0001$ & $(0.000)$ & -2 & 1.10 & $(0.00)$ & 1.26 & $(0.00)$ & -0.16 & $(0.002)$ & $(0.007)$ \\
\hline-1 & $0.3 \%$ & $(0.28)$ & $3.6 \%$ & $(0.00)$ & $-3.3 \%$ & $<.0001$ & $(0.000)$ & -1 & 1.10 & $(0.00)$ & 1.27 & $(0.00)$ & -0.16 & $(0.003)$ & $(0.008)$ \\
\hline 0 & $-1.5 \%$ & $(0.00)$ & $7.4 \%$ & $(0.00)$ & $-8.9 \%$ & $<.0001$ & $(0.000)$ & 0 & 1.11 & $(0.00)$ & 1.30 & $(0.00)$ & -0.19 & $(0.001)$ & $(0.002)$ \\
\hline 1 & $0.0 \%$ & $(0.98)$ & $4.4 \%$ & $(0.00)$ & $-4.4 \%$ & $<.0001$ & $(0.000)$ & 1 & 1.17 & $(0.00)$ & 1.30 & $(0.00)$ & -0.13 & $(0.026)$ & $(0.025)$ \\
\hline 2 & $0.7 \%$ & $(0.02)$ & $4.0 \%$ & $(0.00)$ & $-3.4 \%$ & $<.0001$ & $(0.000)$ & 2 & 1.21 & $(0.00)$ & 1.30 & $(0.00)$ & -0.09 & $(0.161)$ & $(0.138)$ \\
\hline 3 & $1.3 \%$ & $(0.00)$ & $3.7 \%$ & $(0.00)$ & $-2.4 \%$ & $(0.001)$ & $(0.001)$ & 3 & 1.28 & $(0.00)$ & 1.30 & $(0.00)$ & -0.02 & $(0.793)$ & (0.687) \\
\hline 4 & $1.5 \%$ & $(0.00)$ & $3.1 \%$ & $(0.00)$ & $-1.6 \%$ & $(0.010)$ & $(0.009)$ & 4 & 1.30 & $(0.00)$ & 1.31 & $(0.00)$ & -0.01 & $(0.878)$ & (0.841) \\
\hline 5 & $1.5 \%$ & $(0.00)$ & $2.6 \%$ & $(0.00)$ & $-1.1 \%$ & $(0.028)$ & $(0.037)$ & 5 & 1.32 & $(0.00)$ & 1.34 & $(0.00)$ & -0.02 & $(0.760)$ & $(0.960)$ \\
\hline \multicolumn{8}{|c|}{ capital expenditure } & \multicolumn{8}{|c|}{ change in \# of firms } \\
\hline-5 & $8.1 \%$ & $(0.00)$ & $10.2 \%$ & $(0.00)$ & $-2.2 \%$ & $(0.001)$ & $(0.002)$ & -5 & $4.4 \%$ & $(0.05)$ & $8.3 \%$ & $(0.01)$ & $-3.9 \%$ & $(0.272)$ & (0.113) \\
\hline-4 & $8.0 \%$ & $(0.00)$ & $9.9 \%$ & $(0.00)$ & $-1.9 \%$ & $(0.007)$ & $(0.004)$ & -4 & $4.7 \%$ & $(0.05)$ & $5.5 \%$ & $(0.03)$ & $-0.8 \%$ & $(0.811)$ & $(0.724)$ \\
\hline-3 & $7.6 \%$ & $(0.00)$ & $10.9 \%$ & $(0.00)$ & $-3.2 \%$ & $<.0001$ & $(0.000)$ & -3 & $1.4 \%$ & $(0.51)$ & $5.6 \%$ & $(0.01)$ & $-4.2 \%$ & $(0.145)$ & $(0.028)$ \\
\hline-2 & $7.4 \%$ & $(0.00)$ & $10.9 \%$ & $(0.00)$ & $-3.5 \%$ & $<.0001$ & $(0.000)$ & -2 & $2.3 \%$ & $(0.26)$ & $4.2 \%$ & $(0.03)$ & $-2.0 \%$ & $(0.462)$ & $(0.261)$ \\
\hline-1 & $7.0 \%$ & $(0.00)$ & $11.1 \%$ & $(0.00)$ & $-4.1 \%$ & $<.0001$ & $(0.000)$ & -1 & $2.3 \%$ & $(0.29)$ & $5.7 \%$ & $(0.00)$ & $-3.4 \%$ & $(0.215)$ & $(0.022)$ \\
\hline 0 & $6.8 \%$ & $(0.00)$ & $11.9 \%$ & $(0.00)$ & $-5.1 \%$ & $<.0001$ & $(0.000)$ & 0 & $1.9 \%$ & $(0.31)$ & $5.2 \%$ & $(0.01)$ & $-3.4 \%$ & $(0.190)$ & $(0.021)$ \\
\hline 1 & $7.1 \%$ & $(0.00)$ & $11.3 \%$ & $(0.00)$ & $-4.1 \%$ & $<.0001$ & $(0.000)$ & 1 & $1.6 \%$ & $(0.41)$ & $6.9 \%$ & $(0.01)$ & $-5.4 \%$ & $(0.090)$ & (0.019) \\
\hline 2 & $7.5 \%$ & $(0.00)$ & $10.6 \%$ & $(0.00)$ & $-3.1 \%$ & $<.0001$ & $(0.000)$ & 2 & $2.5 \%$ & $(0.11)$ & $4.6 \%$ & $(0.01)$ & $-2.1 \%$ & $(0.357)$ & $(0.124)$ \\
\hline 3 & $7.5 \%$ & $(0.00)$ & $10.3 \%$ & $(0.00)$ & $-2.8 \%$ & $(0.000)$ & $(0.000)$ & 3 & $2.8 \%$ & $(0.14)$ & $4.2 \%$ & $(0.01)$ & $-1.4 \%$ & $(0.550)$ & $(0.332)$ \\
\hline 4 & $7.3 \%$ & $(0.00)$ & $9.8 \%$ & $(0.00)$ & $-2.5 \%$ & $(0.001)$ & $(0.001)$ & 4 & $2.9 \%$ & $(0.21)$ & $3.8 \%$ & $(0.04)$ & $-0.9 \%$ & $(0.753)$ & $(0.326)$ \\
\hline 5 & $7.0 \%$ & $(0.00)$ & $9.4 \%$ & $(0.00)$ & $-2.3 \%$ & $(0.000)$ & $(0.000)$ & 5 & $1.9 \%$ & $(0.32)$ & $4.8 \%$ & $(0.02)$ & $-3.0 \%$ & $(0.271)$ & $(0.066)$ \\
\hline \multicolumn{8}{|c|}{ change in asset } & \multicolumn{8}{|c|}{ cash dividend } \\
\hline-5 & $12.8 \%$ & $(0.00)$ & $14.6 \%$ & $(0.00)$ & $-1.8 \%$ & $(0.400)$ & $(0.268)$ & -5 & $2.2 \%$ & $(0.00)$ & $1.8 \%$ & $(0.00)$ & $0.3 \%$ & $(0.040)$ & $(0.070)$ \\
\hline-4 & $12.3 \%$ & $(0.00)$ & $14.6 \%$ & $(0.00)$ & $-2.3 \%$ & $(0.290)$ & $(0.182)$ & -4 & $2.2 \%$ & $(0.00)$ & $1.8 \%$ & $(0.00)$ & $0.4 \%$ & $(0.008)$ & $(0.016)$ \\
\hline-3 & $10.1 \%$ & $(0.00)$ & $14.6 \%$ & $(0.00)$ & $-4.5 \%$ & $(0.009)$ & $(0.008)$ & -3 & $2.2 \%$ & $(0.00)$ & $1.9 \%$ & $(0.00)$ & $0.3 \%$ & $(0.039)$ & $(0.037)$ \\
\hline-2 & $9.3 \%$ & $(0.00)$ & $17.4 \%$ & $(0.00)$ & $-8.1 \%$ & $(0.001)$ & $(0.000)$ & -2 & $2.2 \%$ & $(0.00)$ & $2.0 \%$ & $(0.00)$ & $0.2 \%$ & $(0.334)$ & $(0.097)$ \\
\hline-1 & $8.6 \%$ & $(0.00)$ & $16.7 \%$ & $(0.00)$ & $-8.1 \%$ & $<.0001$ & $(0.000)$ & -1 & $2.1 \%$ & $(0.00)$ & $1.9 \%$ & $(0.00)$ & $0.2 \%$ & $(0.142)$ & $(0.200)$ \\
\hline 0 & $7.9 \%$ & $(0.00)$ & $22.1 \%$ & $(0.00)$ & $-14.2 \%$ & $<.0001$ & $(0.000)$ & 0 & $2.2 \%$ & $(0.00)$ & $1.9 \%$ & $(0.00)$ & $0.3 \%$ & $(0.069)$ & $(0.047)$ \\
\hline 1 & $9.6 \%$ & $(0.00)$ & $17.2 \%$ & $(0.00)$ & $-7.6 \%$ & $(0.006)$ & $(0.001)$ & 1 & $2.2 \%$ & $(0.00)$ & $1.7 \%$ & $(0.00)$ & $0.5 \%$ & $(0.002)$ & $(0.002)$ \\
\hline 2 & $12.0 \%$ & $(0.00)$ & $15.5 \%$ & $(0.00)$ & $-3.5 \%$ & $(0.112)$ & $(0.056)$ & 2 & $2.2 \%$ & $(0.00)$ & $1.7 \%$ & $(0.00)$ & $0.5 \%$ & $(0.001)$ & $(0.001)$ \\
\hline 3 & $11.5 \%$ & $(0.00)$ & $14.3 \%$ & $(0.00)$ & $-2.8 \%$ & $(0.226)$ & $(0.237)$ & 3 & $2.3 \%$ & $(0.00)$ & $1.7 \%$ & $(0.00)$ & $0.7 \%$ & $<.0001$ & $(0.000)$ \\
\hline 4 & $11.1 \%$ & $(0.00)$ & $14.2 \%$ & $(0.00)$ & $-3.1 \%$ & $(0.157)$ & $(0.047)$ & 4 & $2.1 \%$ & $(0.00)$ & $1.6 \%$ & $(0.00)$ & $0.5 \%$ & $(0.003)$ & $(0.003)$ \\
\hline 5 & $11.1 \%$ & $(0.00)$ & $13.7 \%$ & $(0.00)$ & $-2.6 \%$ & (0.309) & $(0.125)$ & 5 & $2.1 \%$ & $(0.00)$ & $1.7 \%$ & $(0.00)$ & $0.5 \%$ & $(0.020)$ & $(0.024)$ \\
\hline \multicolumn{8}{|c|}{ operating income } & \multicolumn{8}{|c|}{ cash flows } \\
\hline-5 & $16.8 \%$ & $(0.00)$ & $17.2 \%$ & $(0.00)$ & $-0.4 \%$ & $(0.629)$ & $(0.782)$ & -5 & $6.2 \%$ & $(0.00)$ & $6.8 \%$ & $(0.00)$ & $-0.7 \%$ & $(0.061)$ & $(0.125)$ \\
\hline-4 & $16.6 \%$ & $(0.00)$ & $16.7 \%$ & $(0.00)$ & $-0.1 \%$ & $(0.901)$ & $(0.960)$ & -4 & $6.2 \%$ & $(0.00)$ & $6.9 \%$ & $(0.00)$ & $-0.7 \%$ & $(0.084)$ & $(0.083)$ \\
\hline-3 & $16.2 \%$ & $(0.00)$ & $17.6 \%$ & $(0.00)$ & $-1.4 \%$ & $(0.078)$ & $(0.191)$ & -3 & $6.1 \%$ & $(0.00)$ & $6.8 \%$ & $(0.00)$ & $-0.7 \%$ & $(0.038)$ & $(0.031)$ \\
\hline-2 & $15.6 \%$ & $(0.00)$ & $18.4 \%$ & $(0.00)$ & $-2.8 \%$ & $(0.001)$ & $(0.002)$ & -2 & $6.0 \%$ & $(0.00)$ & $7.1 \%$ & $(0.00)$ & $-1.1 \%$ & $(0.001)$ & $(0.001)$ \\
\hline-1 & $16.2 \%$ & $(0.00)$ & $18.3 \%$ & $(0.00)$ & $-2.2 \%$ & $(0.003)$ & $(0.004)$ & -1 & $6.1 \%$ & $(0.00)$ & $7.2 \%$ & $(0.00)$ & $-1.1 \%$ & $(0.001)$ & $(0.002)$ \\
\hline 0 & $16.5 \%$ & $(0.00)$ & $18.7 \%$ & $(0.00)$ & $-2.2 \%$ & $(0.002)$ & $(0.003)$ & 0 & $6.6 \%$ & $(0.00)$ & $7.2 \%$ & $(0.00)$ & $-0.7 \%$ & (0.029) & $(0.102)$ \\
\hline 1 & $16.6 \%$ & $(0.00)$ & $17.6 \%$ & $(0.00)$ & $-0.9 \%$ & $(0.170)$ & $(0.291)$ & 1 & $6.8 \%$ & $(0.00)$ & $6.7 \%$ & $(0.00)$ & $0.0 \%$ & $(0.908)$ & $(0.651)$ \\
\hline 2 & $16.7 \%$ & $(0.00)$ & $16.9 \%$ & $(0.00)$ & $-0.2 \%$ & $(0.775)$ & $(0.633)$ & 2 & $7.0 \%$ & $(0.00)$ & $6.8 \%$ & $(0.00)$ & $0.2 \%$ & $(0.497)$ & $(0.706)$ \\
\hline 3 & $17.2 \%$ & $(0.00)$ & $16.6 \%$ & $(0.00)$ & $0.6 \%$ & $(0.386)$ & $(0.615)$ & 3 & $7.2 \%$ & $(0.00)$ & $6.6 \%$ & $(0.00)$ & $0.6 \%$ & $(0.056)$ & $(0.056)$ \\
\hline 4 & $16.4 \%$ & $(0.00)$ & $16.7 \%$ & $(0.00)$ & $-0.3 \%$ & $(0.627)$ & $(0.466)$ & 4 & $7.2 \%$ & $(0.00)$ & $6.9 \%$ & $(0.00)$ & $0.3 \%$ & $(0.282)$ & $(0.302)$ \\
\hline 5 & $16.5 \%$ & $(0.00)$ & $16.3 \%$ & $(0.00)$ & $0.2 \%$ & $(0.747)$ & $(0.801)$ & 5 & $7.0 \%$ & $(0.00)$ & $6.9 \%$ & $(0.00)$ & $0.0 \%$ & $(0.935)$ & $(0.763)$ \\
\hline
\end{tabular}


Table 4. cont.

Panel B. 11-year analysis for the $2^{\text {nd }}$ sub-period (1997-2009 funding years)

\begin{tabular}{|c|c|c|c|c|c|c|c|c|c|c|c|c|c|c|c|}
\hline $\begin{array}{c}\text { year } \\
\text { relative } \\
\text { to } \\
\text { funding }\end{array}$ & $\begin{array}{l}\text { "low- } \\
\text { funded" } \\
\text { quintile }\end{array}$ & (p-val) & $\begin{array}{c}\text { "high- } \\
\text { funded" } \\
\text { quintile }\end{array}$ & (p-val) & $\begin{array}{l}\text { "low" } \\
\text { minus } \\
\text { "high" }\end{array}$ & $\begin{array}{r}\text { (p-val: } \\
\text { mean } \\
\text { diff) }\end{array}$ & $\begin{array}{r}(\mathrm{p}-\mathrm{val}: \\
\text { median } \\
\text { diff) }\end{array}$ & $\begin{array}{c}\text { year } \\
\text { relative } \\
\text { to } \\
\text { funding }\end{array}$ & $\begin{array}{c}\text { "low- } \\
\text { funded" } \\
\text { quintile }\end{array}$ & (p-val) & $\begin{array}{l}\text { "high- } \\
\text { funded" } \\
\text { quintile }\end{array}$ & (p-val) & $\begin{array}{l}\text { "low" } \\
\text { minus } \\
\text { "high" }\end{array}$ & $\begin{array}{r}\text { (p-val: } \\
\text { mean } \\
\text { diff) }\end{array}$ & $\begin{array}{r}(\mathrm{p}-\mathrm{val} \\
\text { median } \\
\text { diff }\end{array}$ \\
\hline \multicolumn{8}{|c|}{ total funding rate } & \multicolumn{8}{|l|}{ q ratio } \\
\hline-5 & $1.3 \%$ & $(0.08)$ & $1.7 \%$ & $(0.01)$ & $-0.4 \%$ & $(0.622)$ & $(0.412)$ & -5 & 1.57 & $(0.00)$ & 1.28 & $(0.00)$ & 0.29 & $(0.003)$ & $(0.004)$ \\
\hline-4 & $0.7 \%$ & $(0.28)$ & $2.0 \%$ & $(0.00)$ & $-1.3 \%$ & $(0.106)$ & $(0.031)$ & -4 & 1.58 & $(0.00)$ & 1.28 & $(0.00)$ & 0.30 & $(0.005)$ & $(0.004)$ \\
\hline-3 & $0.7 \%$ & $(0.18)$ & $2.1 \%$ & $(0.01)$ & $-1.4 \%$ & $(0.105)$ & $(0.200)$ & -3 & 1.55 & $(0.00)$ & 1.32 & $(0.00)$ & 0.22 & $(0.022)$ & $(0.012)$ \\
\hline-2 & $-0.3 \%$ & $(0.43)$ & $2.8 \%$ & $(0.00)$ & $-3.2 \%$ & $(0.000)$ & $(0.000)$ & -2 & 1.59 & $(0.00)$ & 1.35 & $(0.00)$ & 0.23 & $(0.015)$ & $(0.021)$ \\
\hline-1 & $-1.1 \%$ & $(0.02)$ & $3.4 \%$ & $(0.00)$ & $-4.5 \%$ & $<.0001$ & $(0.000)$ & -1 & 1.59 & $(0.00)$ & 1.40 & $(0.00)$ & 0.19 & $(0.066)$ & $(0.091)$ \\
\hline 0 & $-3.2 \%$ & $(0.00)$ & $5.9 \%$ & $(0.00)$ & $-9.1 \%$ & $<.0001$ & $(0.000)$ & 0 & 1.58 & $(0.00)$ & 1.37 & $(0.00)$ & 0.21 & $(0.027)$ & $(0.058)$ \\
\hline 1 & $-1.0 \%$ & $(0.05)$ & $2.3 \%$ & $(0.00)$ & $-3.3 \%$ & $<.0001$ & $(0.000)$ & 1 & 1.56 & $(0.00)$ & 1.32 & $(0.00)$ & 0.25 & $(0.019)$ & $(0.046)$ \\
\hline 2 & $-0.8 \%$ & $(0.16)$ & $1.1 \%$ & $(0.01)$ & $-1.9 \%$ & $(0.005)$ & $(0.009)$ & 2 & 1.55 & $(0.00)$ & 1.35 & $(0.00)$ & 0.21 & $(0.044)$ & $(0.040)$ \\
\hline 3 & $-0.9 \%$ & $(0.05)$ & $0.1 \%$ & $(0.65)$ & $-1.0 \%$ & $(0.054)$ & $(0.124)$ & 3 & 1.57 & $(0.00)$ & 1.30 & $(0.00)$ & 0.26 & $(0.002)$ & $(0.005)$ \\
\hline 4 & $-0.9 \%$ & $(0.02)$ & $0.3 \%$ & $(0.36)$ & $-1.2 \%$ & $(0.014)$ & $(0.027)$ & 4 & 1.55 & $(0.00)$ & 1.30 & $(0.00)$ & 0.25 & $(0.008)$ & $(0.024)$ \\
\hline 5 & $-0.9 \%$ & $(0.08)$ & $0.0 \%$ & $(0.98)$ & $-0.9 \%$ & $(0.172)$ & $(0.200)$ & 5 & 1.59 & $(0.00)$ & 1.31 & $(0.00)$ & 0.28 & $(0.003)$ & $(0.007)$ \\
\hline \multicolumn{8}{|c|}{ capital expenditure } & \multicolumn{8}{|c|}{ change in \# of firms } \\
\hline-5 & $5.9 \%$ & $(0.00)$ & $6.3 \%$ & $(0.00)$ & $-0.4 \%$ & $(0.567)$ & $(0.608)$ & -5 & $-2.1 \%$ & $(0.16)$ & $-1.4 \%$ & $(0.34)$ & $-0.6 \%$ & $(0.755)$ & $(0.538)$ \\
\hline-4 & $5.5 \%$ & $(0.00)$ & $6.2 \%$ & $(0.00)$ & $-0.7 \%$ & $(0.325)$ & $(0.305)$ & -4 & $-3.9 \%$ & $(0.01)$ & $-1.9 \%$ & $(0.31)$ & $-2.0 \%$ & $(0.366)$ & $(0.473)$ \\
\hline-3 & $5.2 \%$ & $(0.00)$ & $6.1 \%$ & $(0.00)$ & $-0.8 \%$ & $(0.237)$ & $(0.330)$ & -3 & $-3.0 \%$ & $(0.04)$ & $-2.7 \%$ & $(0.13)$ & $-0.3 \%$ & $(0.893)$ & $(0.798)$ \\
\hline-2 & $4.8 \%$ & $(0.00)$ & $6.5 \%$ & $(0.00)$ & $-1.7 \%$ & $(0.016)$ & $(0.016)$ & -2 & $-4.6 \%$ & $(0.01)$ & $-1.2 \%$ & $(0.26)$ & $-3.4 \%$ & $(0.064)$ & $(0.012)$ \\
\hline-1 & $4.6 \%$ & $(0.00)$ & $6.2 \%$ & $(0.00)$ & $-1.5 \%$ & $(0.011)$ & $(0.014)$ & -1 & $-5.6 \%$ & $(0.00)$ & $-3.5 \%$ & $(0.00)$ & $-2.1 \%$ & $(0.102)$ & $(0.040)$ \\
\hline 0 & $4.3 \%$ & $(0.00)$ & $6.2 \%$ & $(0.00)$ & $-1.9 \%$ & $(0.005)$ & $(0.006)$ & 0 & $-3.9 \%$ & $(0.00)$ & $-3.4 \%$ & $(0.00)$ & $-0.5 \%$ & $(0.747)$ & $(0.837)$ \\
\hline 1 & $4.3 \%$ & $(0.00)$ & $5.2 \%$ & $(0.00)$ & $-0.9 \%$ & $(0.053)$ & $(0.065)$ & 1 & $-5.0 \%$ & $(0.00)$ & $-3.8 \%$ & $(0.00)$ & $-1.2 \%$ & $(0.240)$ & $(0.166)$ \\
\hline 2 & $4.2 \%$ & $(0.00)$ & $4.8 \%$ & $(0.00)$ & $-0.7 \%$ & $(0.082)$ & $(0.091)$ & 2 & $-4.7 \%$ & $(0.00)$ & $-4.4 \%$ & $(0.00)$ & $-0.3 \%$ & $(0.767)$ & $(0.959)$ \\
\hline 3 & $4.0 \%$ & $(0.00)$ & $4.7 \%$ & $(0.00)$ & $-0.6 \%$ & $(0.104)$ & $(0.124)$ & 3 & $-3.5 \%$ & $(0.00)$ & $-4.8 \%$ & $(0.00)$ & $1.3 \%$ & $(0.282)$ & $(0.281)$ \\
\hline 4 & $3.9 \%$ & $(0.00)$ & $4.5 \%$ & $(0.00)$ & $-0.5 \%$ & $(0.090)$ & $(0.051)$ & 4 & $-3.3 \%$ & $(0.01)$ & $-4.3 \%$ & $(0.00)$ & $1.0 \%$ & $(0.509)$ & $(0.720)$ \\
\hline 5 & $3.9 \%$ & $(0.00)$ & $4.4 \%$ & $(0.00)$ & $-0.5 \%$ & $(0.093)$ & $(0.036)$ & 5 & $-3.4 \%$ & $(0.00)$ & $-5.0 \%$ & $(0.00)$ & $1.6 \%$ & $(0.279)$ & $(0.218$ \\
\hline \multicolumn{8}{|c|}{ change in asset } & \multicolumn{8}{|c|}{ cash dividend } \\
\hline-5 & $8.4 \%$ & $(0.00)$ & $10.1 \%$ & $(0.00)$ & $-1.8 \%$ & $(0.300)$ & $(0.305)$ & -5 & $1.6 \%$ & $(0.00)$ & $1.3 \%$ & $(0.00)$ & $0.3 \%$ & $(0.203)$ & $(0.259)$ \\
\hline-4 & $9.6 \%$ & $(0.00)$ & $11.4 \%$ & $(0.00)$ & $-1.8 \%$ & $(0.378)$ & $(0.218)$ & -4 & $1.6 \%$ & $(0.00)$ & $1.3 \%$ & $(0.00)$ & $0.4 \%$ & $(0.047)$ & $(0.124)$ \\
\hline-3 & $8.9 \%$ & $(0.00)$ & $11.7 \%$ & $(0.00)$ & $-2.8 \%$ & $(0.117)$ & $(0.305)$ & -3 & $1.6 \%$ & $(0.00)$ & $1.2 \%$ & $(0.00)$ & $0.4 \%$ & $(0.028)$ & $(0.027)$ \\
\hline-2 & $7.9 \%$ & $(0.00)$ & $12.1 \%$ & $(0.00)$ & $-4.2 \%$ & $(0.035)$ & $(0.040)$ & -2 & $1.6 \%$ & $(0.00)$ & $1.3 \%$ & $(0.00)$ & $0.3 \%$ & $(0.182)$ & $(0.238)$ \\
\hline-1 & $5.8 \%$ & $(0.00)$ & $12.0 \%$ & $(0.00)$ & $-6.1 \%$ & $(0.011)$ & $(0.016)$ & -1 & $1.5 \%$ & $(0.00)$ & $1.3 \%$ & $(0.00)$ & $0.2 \%$ & $(0.379)$ & $(0.330)$ \\
\hline 0 & $3.7 \%$ & $(0.00)$ & $16.3 \%$ & $(0.00)$ & $-12.6 \%$ & $(0.001)$ & $(0.000)$ & 0 & $1.5 \%$ & $(0.00)$ & $1.2 \%$ & $(0.00)$ & $0.3 \%$ & $(0.070)$ & $(0.073)$ \\
\hline 1 & $6.6 \%$ & $(0.00)$ & $8.7 \%$ & $(0.00)$ & $-2.1 \%$ & $(0.280)$ & $(0.238)$ & 1 & $1.7 \%$ & $(0.00)$ & $1.1 \%$ & $(0.00)$ & $0.6 \%$ & $(0.001)$ & $(0.001)$ \\
\hline 2 & $7.1 \%$ & $(0.00)$ & $7.0 \%$ & $(0.00)$ & $0.1 \%$ & $(0.950)$ & $(1.000)$ & 2 & $1.8 \%$ & $(0.00)$ & $1.1 \%$ & $(0.00)$ & $0.7 \%$ & $(0.003)$ & $(0.004)$ \\
\hline 3 & $8.2 \%$ & $(0.00)$ & $5.2 \%$ & $(0.00)$ & $3.0 \%$ & $(0.036)$ & $(0.065)$ & 3 & $1.7 \%$ & $(0.00)$ & $1.2 \%$ & $(0.00)$ & $0.5 \%$ & $(0.028)$ & $(0.012)$ \\
\hline 4 & $7.6 \%$ & $(0.00)$ & $6.1 \%$ & $(0.00)$ & $1.5 \%$ & $(0.354)$ & $(0.383)$ & 4 & $1.9 \%$ & $(0.00)$ & $1.3 \%$ & $(0.00)$ & $0.7 \%$ & $(0.005)$ & $(0.008)$ \\
\hline 5 & $8.1 \%$ & $(0.00)$ & $5.3 \%$ & $(0.00)$ & $2.8 \%$ & $(0.045)$ & $(0.065)$ & 5 & $2.1 \%$ & $(0.00)$ & $1.4 \%$ & $(0.00)$ & $0.7 \%$ & $(0.003)$ & $(0.005$ \\
\hline \multicolumn{8}{|c|}{ operating income } & \multicolumn{8}{|c|}{ cash flows } \\
\hline-5 & $15.0 \%$ & $(0.00)$ & $14.8 \%$ & $(0.00)$ & $0.2 \%$ & $(0.837)$ & $(0.538)$ & -5 & $7.7 \%$ & $(0.00)$ & $6.9 \%$ & $(0.00)$ & $0.7 \%$ & $(0.122)$ & $(0.124)$ \\
\hline-4 & $15.1 \%$ & $(0.00)$ & $14.6 \%$ & $(0.00)$ & $0.5 \%$ & $(0.496)$ & $(0.238)$ & -4 & $7.5 \%$ & $(0.00)$ & $6.9 \%$ & $(0.00)$ & $0.6 \%$ & $(0.224)$ & $(0.238)$ \\
\hline-3 & $14.5 \%$ & $(0.00)$ & $14.7 \%$ & $(0.00)$ & $-0.3 \%$ & $(0.728)$ & $(0.758)$ & -3 & $7.3 \%$ & $(0.00)$ & $7.1 \%$ & $(0.00)$ & $0.1 \%$ & $(0.672)$ & $(0.505)$ \\
\hline-2 & $14.9 \%$ & $(0.00)$ & $15.1 \%$ & $(0.00)$ & $-0.2 \%$ & $(0.784)$ & $(0.798)$ & -2 & $7.4 \%$ & $(0.00)$ & $7.2 \%$ & $(0.00)$ & $0.2 \%$ & $(0.507)$ & $(0.505)$ \\
\hline-1 & $14.3 \%$ & $(0.00)$ & $14.3 \%$ & $(0.00)$ & $0.0 \%$ & $(0.956)$ & $(0.918)$ & -1 & $7.4 \%$ & $(0.00)$ & $6.9 \%$ & $(0.00)$ & $0.5 \%$ & $(0.121)$ & $(0.166)$ \\
\hline 0 & $14.7 \%$ & $(0.00)$ & $13.8 \%$ & $(0.00)$ & $0.8 \%$ & $(0.256)$ & $(0.330)$ & 0 & $7.4 \%$ & $(0.00)$ & $6.8 \%$ & $(0.00)$ & $0.7 \%$ & $(0.016)$ & $(0.024)$ \\
\hline 1 & $14.8 \%$ & $(0.00)$ & $13.0 \%$ & $(0.00)$ & $1.9 \%$ & $(0.010)$ & $(0.018)$ & 1 & $7.8 \%$ & $(0.00)$ & $6.4 \%$ & $(0.00)$ & $1.4 \%$ & $(0.000)$ & $(0.001)$ \\
\hline 2 & $15.4 \%$ & $(0.00)$ & $13.2 \%$ & $(0.00)$ & $2.2 \%$ & $(0.002)$ & $(0.003)$ & 2 & $7.7 \%$ & $(0.00)$ & $6.7 \%$ & $(0.00)$ & $1.0 \%$ & $(0.005)$ & $(0.003)$ \\
\hline 3 & $14.7 \%$ & $(0.00)$ & $13.1 \%$ & $(0.00)$ & $1.7 \%$ & $(0.003)$ & $(0.002)$ & 3 & $8.0 \%$ & $(0.00)$ & $7.2 \%$ & $(0.00)$ & $0.8 \%$ & $(0.028)$ & $(0.031)$ \\
\hline 4 & $14.5 \%$ & $(0.00)$ & $13.3 \%$ & $(0.00)$ & $1.1 \%$ & $(0.016)$ & $(0.031)$ & 4 & $7.9 \%$ & $(0.00)$ & $7.0 \%$ & $(0.00)$ & $0.8 \%$ & $(0.001)$ & $(0.004)$ \\
\hline 5 & $14.6 \%$ & $(0.00)$ & $13.1 \%$ & $(0.00)$ & $1.5 \%$ & $(0.005)$ & $(0.005)$ & 5 & $7.7 \%$ & $(0.00)$ & $7.2 \%$ & $(0.00)$ & $0.5 \%$ & $(0.064)$ & $(0.073)$ \\
\hline
\end{tabular}


Table 5. Panel regressions of industry total funding rate on industry $q$

The sample period is from 1971 to 2014. The industries are the Fama-French 48 industries. The funding rate of an industry is the sum of all equity and debt funds raised by the industry's firms during the year, divided by the sum of those firms' total assets at the start of the year. The industry q is the ratio of market value of assets to book value of assets, all at the end of the previous year. Within an industry, each characteristic is summed across companies and then the ratio is computed for the industry. To control for year fixed-effects, all variables are de-meaned by year-specific averages. Intercept is in the regressions but not reported below. P-values in parentheses are based on two-way cluster-robust standard errors (i.e., industry and year).

Panel A. Entire sample period (1971-2014)

\begin{tabular}{|c|c|c|c|}
\hline \multirow[b]{2}{*}{ regressors } & \multicolumn{3}{|c|}{ dependent variable: industry total funding rate } \\
\hline & Est. (p-val) & Est. (p-val) & Est. (p-val) \\
\hline industry q & $0.004 \quad(0.480)$ & $0.006(0.189)$ & $0.005(0.246)$ \\
\hline concurrent cashflow & $-0.602(0.000)$ & $-0.735(0.000)$ & $-0.716(0.000)$ \\
\hline lagged cashflow & $0.454(0.000)$ & $0.309(0.000)$ & $0.314(0.000)$ \\
\hline lagged capex & & & $-0.079(0.487)$ \\
\hline concurrent capex & & $0.532(0.000)$ & $0.654(0.018)$ \\
\hline lead capex & & & $-0.083(0.648)$ \\
\hline \# observations & 1736 & 1736 & 1666 \\
\hline$R^{2}$ & $5.5 \%$ & $18.9 \%$ & $18.7 \%$ \\
\hline
\end{tabular}

Panel B. First sub-period (1971-1996)

\begin{tabular}{|c|c|c|c|}
\hline \multirow[b]{2}{*}{ regressors } & \multicolumn{3}{|c|}{ dependent variable: industry total funding rate } \\
\hline & Est. (p-val) & Est. (p-val) & Est. (p-val) \\
\hline industry q & $0.014(0.085)$ & $0.010(0.015)$ & $0.009(0.029)$ \\
\hline concurrent cashflow & $-0.725(0.006)$ & $-0.887(0.000)$ & $-0.852(0.000)$ \\
\hline lagged cashflow & $0.527(0.000)$ & $0.381 \quad(0.011)$ & $0.353(0.005)$ \\
\hline lagged capex & & & $0.041 \quad(0.574)$ \\
\hline concurrent capex & & $0.537(0.000)$ & $0.381 \quad(0.017)$ \\
\hline lead capex & & & $0.118(0.346)$ \\
\hline \# observations & 1015 & 1015 & 993 \\
\hline$R^{2}$ & $11.7 \%$ & $32.3 \%$ & $33.1 \%$ \\
\hline
\end{tabular}


Panel C. Second sub-period (1997-2014)

dependent variable: industry total funding rate

\begin{tabular}{|c|c|c|c|}
\hline regressors & Est. (p-val) & Est. (p-val) & Est. (p-val) \\
\hline industry $\mathrm{q}$ & $-0.003(0.607)$ & $0.002(0.738)$ & $0.000(0.933)$ \\
\hline concurrent cashflow & $-0.414 \quad(0.004)$ & $-0.495(0.001)$ & $-0.485(0.002)$ \\
\hline lagged cashflow & $0.342(0.032)$ & $0.204(0.056)$ & $0.248 \quad(0.107)$ \\
\hline lagged capex & & & $-0.809 \quad(0.084)$ \\
\hline concurrent capex & & $0.514(0.021)$ & $2.400 \quad(0.030)$ \\
\hline lead capex & & & $-1.239(0.028)$ \\
\hline \# observations & 721 & 721 & 673 \\
\hline$R^{2}$ & $2.0 \%$ & $8.5 \%$ & $18.5 \%$ \\
\hline
\end{tabular}


Table 6. Median industry total, equity, and debt funding rate of low- and high-funded industry quintiles

The industries are the Fama-French 48 industries. The funding rate of an industry is the sum of all equity and debt funds raised by the industry's firms during the year, divided by the sum of those firms' total assets at the start of the year. The equity (debt) funding rate of an industry is the sum of all equity (debt) raised by the industry's firms during the year, divided by the sum of those firms' total assets at the start of the year. The quintiles are identified each year, based on the total (i.e., equity + debt) funding rate.

\begin{tabular}{|c|c|c|c|c|c|c|c|c|c|c|c|c|}
\hline \multirow[b]{2}{*}{ year } & \multicolumn{4}{|c|}{ median total funding rate } & \multicolumn{4}{|c|}{ median equity funding rate } & \multicolumn{4}{|c|}{ median debt funding rate } \\
\hline & $\begin{array}{l}\text { low- } \\
\text { funded } \\
\text { quintile }\end{array}$ & $\begin{array}{l}\text { high- } \\
\text { funded } \\
\text { quintile }\end{array}$ & $\begin{array}{l}\text { p-val for: } \\
\text { low>high } \\
\text { (1-sided } \\
\text { Wilcoxon) }\end{array}$ & $\begin{array}{l}\text { p-val for: } \\
\text { low=high } \\
\text { (2-sided } \\
\text { Wilcoxon) }\end{array}$ & $\begin{array}{l}\text { low- } \\
\text { funded } \\
\text { quintile }\end{array}$ & $\begin{array}{l}\text { high- } \\
\text { funded } \\
\text { quintile }\end{array}$ & $\begin{array}{l}\text { p-val for: } \\
\text { low>high } \\
\text { (1-sided } \\
\text { Wilcoxon) }\end{array}$ & $\begin{array}{l}\text { p-val for: } \\
\text { low=high } \\
\text { (2-sided } \\
\text { Wilcoxon) }\end{array}$ & $\begin{array}{l}\text { low- } \\
\text { funded } \\
\text { quintile }\end{array}$ & $\begin{array}{l}\text { high- } \\
\text { funded } \\
\text { quintile }\end{array}$ & $\begin{array}{l}\text { p-val for: } \\
\text { low>high } \\
\text { (1-sided } \\
\text { Wilcoxon) }\end{array}$ & $\begin{array}{l}\text { p-val for: } \\
\text { low=high } \\
\text { (2-sided } \\
\text { Wilcoxon) }\end{array}$ \\
\hline 1971 & $0.6 \%$ & $7.5 \%$ & $(0.001)$ & $(0.002)$ & $0.8 \%$ & $2.6 \%$ & $(0.020)$ & $(0.041)$ & $-0.6 \%$ & $5.7 \%$ & $(0.001)$ & $(0.002)$ \\
\hline 1972 & $0.4 \%$ & $6.5 \%$ & $(0.001)$ & $(0.001)$ & $0.2 \%$ & $2.1 \%$ & $(0.009)$ & $(0.018)$ & $-0.7 \%$ & $4.7 \%$ & $(0.001)$ & $(0.001)$ \\
\hline 1973 & $-0.1 \%$ & $6.4 \%$ & $(0.001)$ & $(0.001)$ & $-0.4 \%$ & $0.1 \%$ & $(0.006)$ & $(0.013)$ & $0.1 \%$ & $5.5 \%$ & $(0.001)$ & $(0.001)$ \\
\hline 1974 & $-0.5 \%$ & $6.0 \%$ & $(0.001)$ & $(0.001)$ & $0.0 \%$ & $0.1 \%$ & $(0.112)$ & $(0.224)$ & $-0.5 \%$ & $5.2 \%$ & $(0.001)$ & $(0.001)$ \\
\hline 1975 & $-2.0 \%$ & $4.8 \%$ & $(0.000)$ & $(0.001)$ & $0.1 \%$ & $0.6 \%$ & $(0.042)$ & $(0.083)$ & $-2.4 \%$ & $4.2 \%$ & $(0.000)$ & $(0.001)$ \\
\hline 1976 & $-1.3 \%$ & $3.5 \%$ & $(0.000)$ & $(0.001)$ & $0.1 \%$ & $0.9 \%$ & $(0.007)$ & $(0.014)$ & $-1.2 \%$ & $3.1 \%$ & $(0.001)$ & $(0.001)$ \\
\hline 1977 & $-0.3 \%$ & $4.6 \%$ & $(0.001)$ & $(0.001)$ & $-0.1 \%$ & $0.7 \%$ & $(0.016)$ & $(0.032)$ & $-0.4 \%$ & $3.5 \%$ & $(0.001)$ & $(0.001)$ \\
\hline 1978 & $-0.1 \%$ & $6.6 \%$ & $(0.001)$ & $(0.001)$ & $0.0 \%$ & $0.9 \%$ & $(0.006)$ & $(0.013)$ & $-0.1 \%$ & $4.4 \%$ & $(0.001)$ & $(0.001)$ \\
\hline 1979 & $0.3 \%$ & $7.7 \%$ & $(0.001)$ & $(0.002)$ & $0.0 \%$ & $0.7 \%$ & $(0.125)$ & $(0.250)$ & $0.5 \%$ & $7.4 \%$ & $(0.001)$ & $(0.002)$ \\
\hline 1980 & $0.5 \%$ & $6.7 \%$ & $(0.001)$ & $(0.002)$ & $0.3 \%$ & $2.5 \%$ & $(0.004)$ & $(0.007)$ & $0.4 \%$ & $5.2 \%$ & $(0.001)$ & $(0.002)$ \\
\hline 1981 & $0.1 \%$ & $11.5 \%$ & $(0.001)$ & $(0.002)$ & $0.0 \%$ & $5.8 \%$ & $(0.001)$ & $(0.002)$ & $0.0 \%$ & $2.9 \%$ & $(0.001)$ & $(0.002)$ \\
\hline 1982 & $-0.4 \%$ & $8.2 \%$ & $(0.001)$ & $(0.002)$ & $0.0 \%$ & $4.7 \%$ & $(0.004)$ & $(0.007)$ & $-0.6 \%$ & $4.6 \%$ & $(0.001)$ & $(0.002)$ \\
\hline 1983 & $-1.3 \%$ & $8.8 \%$ & $(0.001)$ & $(0.002)$ & $0.3 \%$ & $4.8 \%$ & $(0.001)$ & $(0.002)$ & $-2.1 \%$ & $4.4 \%$ & $(0.002)$ & $(0.003)$ \\
\hline 1984 & $-1.7 \%$ & $7.9 \%$ & $(0.001)$ & $(0.002)$ & $-0.9 \%$ & $0.5 \%$ & $(0.125)$ & $(0.250)$ & $-1.1 \%$ & $6.8 \%$ & $(0.001)$ & $(0.002)$ \\
\hline 1985 & $-0.9 \%$ & $8.7 \%$ & $(0.001)$ & $(0.001)$ & $-0.3 \%$ & $2.7 \%$ & $(0.009)$ & $(0.018)$ & $-0.2 \%$ & $7.2 \%$ & $(0.001)$ & $(0.001)$ \\
\hline 1986 & $-1.2 \%$ & $11.7 \%$ & $(0.001)$ & $(0.001)$ & $-2.5 \%$ & $4.5 \%$ & $(0.002)$ & $(0.005)$ & $0.1 \%$ & $8.5 \%$ & $(0.005)$ & $(0.009)$ \\
\hline 1987 & $-4.4 \%$ & $12.4 \%$ & $(0.000)$ & $(0.001)$ & $-2.1 \%$ & $2.6 \%$ & $(0.005)$ & $(0.010)$ & $-3.2 \%$ & $9.6 \%$ & $(0.000)$ & $(0.001)$ \\
\hline 1988 & $-5.0 \%$ & $5.7 \%$ & $(0.001)$ & $(0.001)$ & $-1.3 \%$ & $0.3 \%$ & $(0.074)$ & $(0.148)$ & $-2.4 \%$ & $6.3 \%$ & $(0.001)$ & $(0.001)$ \\
\hline 1989 & $-2.5 \%$ & $5.6 \%$ & $(0.001)$ & $(0.001)$ & $-0.3 \%$ & $-0.3 \%$ & $(0.262)$ & $(0.524)$ & $-2.9 \%$ & $5.8 \%$ & $(0.001)$ & $(0.001)$ \\
\hline 1990 & $-3.0 \%$ & $3.4 \%$ & $(0.001)$ & $(0.001)$ & $-0.5 \%$ & $-0.4 \%$ & $(0.262)$ & $(0.524)$ & $-2.2 \%$ & $3.1 \%$ & $(0.001)$ & $(0.001)$ \\
\hline 1991 & $-1.5 \%$ & $4.9 \%$ & $(0.001)$ & $(0.001)$ & $0.4 \%$ & $2.4 \%$ & $(0.009)$ & $(0.018)$ & $-2.4 \%$ & $2.0 \%$ & $(0.001)$ & $(0.002)$ \\
\hline 1992 & $-0.7 \%$ & $4.8 \%$ & $(0.000)$ & $(0.001)$ & $-0.7 \%$ & $2.7 \%$ & $(0.020)$ & $(0.041)$ & $-1.1 \%$ & $2.8 \%$ & $(0.007)$ & $(0.014)$ \\
\hline 1993 & $-1.8 \%$ & $4.3 \%$ & $(0.000)$ & $(0.001)$ & $-0.1 \%$ & $2.1 \%$ & $(0.001)$ & $(0.001)$ & $-1.0 \%$ & $2.1 \%$ & $(0.001)$ & $(0.002)$ \\
\hline 1994 & $-2.9 \%$ & $7.1 \%$ & $(0.001)$ & $(0.001)$ & $-0.6 \%$ & $2.4 \%$ & $(0.006)$ & $(0.013)$ & $-1.7 \%$ & $5.5 \%$ & $(0.001)$ & $(0.001)$ \\
\hline 1995 & $-1.9 \%$ & $8.7 \%$ & $(0.000)$ & $(0.001)$ & $-1.2 \%$ & $2.2 \%$ & $(0.007)$ & $(0.014)$ & $-0.7 \%$ & $7.5 \%$ & $(0.000)$ & $(0.001)$ \\
\hline 1996 & $-2.3 \%$ & $12.1 \%$ & $(0.000)$ & $(0.001)$ & $-2.4 \%$ & $3.0 \%$ & $(0.001)$ & $(0.002)$ & $-0.6 \%$ & $7.8 \%$ & $(0.000)$ & $(0.001)$ \\
\hline 1997 & $-1.8 \%$ & $10.6 \%$ & $(0.000)$ & $(0.001)$ & $-2.5 \%$ & $1.4 \%$ & $(0.001)$ & $(0.003)$ & $-0.2 \%$ & $10.2 \%$ & $(0.000)$ & $(0.001)$ \\
\hline 1998 & $-1.4 \%$ & $7.8 \%$ & $(0.000)$ & $(0.001)$ & $-1.8 \%$ & $0.1 \%$ & $(0.007)$ & $(0.014)$ & $1.1 \%$ & $7.5 \%$ & $(0.000)$ & $(0.001)$ \\
\hline 1999 & $-1.1 \%$ & $8.5 \%$ & $(0.000)$ & $(0.001)$ & $-3.0 \%$ & $2.3 \%$ & $(0.002)$ & $(0.004)$ & $1.5 \%$ & $6.1 \%$ & $(0.001)$ & $(0.003)$ \\
\hline 2000 & $-2.3 \%$ & $7.2 \%$ & $(0.000)$ & $(0.001)$ & $-0.8 \%$ & $3.3 \%$ & $(0.033)$ & $(0.066)$ & $-2.0 \%$ & $5.2 \%$ & $(0.000)$ & $(0.001)$ \\
\hline 2001 & $-2.7 \%$ & $5.7 \%$ & $(0.000)$ & $(0.001)$ & $-0.2 \%$ & $0.2 \%$ & $(0.186)$ & $(0.372)$ & $-2.3 \%$ & $4.5 \%$ & $(0.000)$ & $(0.001)$ \\
\hline 2002 & $-3.2 \%$ & $3.0 \%$ & $(0.001)$ & $(0.001)$ & $0.4 \%$ & $0.1 \%$ & . & $(0.685)$ & $-4.2 \%$ & $2.7 \%$ & $(0.003)$ & $(0.007)$ \\
\hline 2003 & $-3.2 \%$ & $6.7 \%$ & $(0.000)$ & $(0.001)$ & $-1.5 \%$ & $-0.1 \%$ & $(0.002)$ & $(0.004)$ & $-1.5 \%$ & $4.1 \%$ & $(0.007)$ & $(0.014)$ \\
\hline 2004 & $-4.0 \%$ & $5.1 \%$ & $(0.000)$ & $(0.001)$ & $-2.2 \%$ & $1.7 \%$ & $(0.000)$ & $(0.001)$ & $-1.3 \%$ & $3.4 \%$ & $(0.001)$ & $(0.002)$ \\
\hline 2005 & $-4.5 \%$ & $3.2 \%$ & $(0.000)$ & $(0.001)$ & $-2.8 \%$ & $0.0 \%$ & $(0.001)$ & $(0.001)$ & $-1.9 \%$ & $3.8 \%$ & $(0.001)$ & $(0.003)$ \\
\hline 2006 & $-4.0 \%$ & $4.3 \%$ & $(0.000)$ & $(0.001)$ & $-5.1 \%$ & $1.6 \%$ & $(0.000)$ & $(0.001)$ & $0.7 \%$ & $3.5 \%$ & $(0.020)$ & $(0.041)$ \\
\hline 2007 & $-5.7 \%$ & $7.3 \%$ & $(0.000)$ & $(0.001)$ & $-4.5 \%$ & $-0.7 \%$ & $(0.009)$ & $(0.018)$ & $-1.3 \%$ & $8.0 \%$ & $(0.000)$ & $(0.001)$ \\
\hline 2008 & $-4.0 \%$ & $4.0 \%$ & $(0.000)$ & $(0.001)$ & $-4.3 \%$ & $-0.2 \%$ & $(0.001)$ & $(0.001)$ & $0.0 \%$ & $5.1 \%$ & $(0.001)$ & $(0.001)$ \\
\hline 2009 & $-3.5 \%$ & $4.0 \%$ & $(0.000)$ & $(0.001)$ & $0.0 \%$ & $2.1 \%$ & $(0.005)$ & $(0.010)$ & $-3.5 \%$ & $2.5 \%$ & $(0.000)$ & $(0.001)$ \\
\hline 2010 & $-4.2 \%$ & $3.0 \%$ & $(0.000)$ & $(0.001)$ & $-3.2 \%$ & $-0.6 \%$ & $(0.064)$ & $(0.128)$ & $-0.8 \%$ & $5.0 \%$ & $(0.001)$ & $(0.001)$ \\
\hline 2011 & $-3.7 \%$ & $2.8 \%$ & $(0.001)$ & $(0.001)$ & $-4.4 \%$ & $-1.3 \%$ & $(0.003)$ & $(0.007)$ & $0.5 \%$ & $4.4 \%$ & $(0.001)$ & $(0.002)$ \\
\hline 2012 & $-2.0 \%$ & $4.3 \%$ & $(0.000)$ & $(0.001)$ & $-2.0 \%$ & $-0.3 \%$ & $(0.012)$ & $(0.024)$ & $0.6 \%$ & $4.8 \%$ & $(0.000)$ & $(0.001)$ \\
\hline 2013 & $-3.1 \%$ & $4.3 \%$ & $(0.000)$ & $(0.001)$ & $-3.1 \%$ & $0.6 \%$ & $(0.001)$ & $(0.001)$ & $0.4 \%$ & $4.6 \%$ & $(0.001)$ & $(0.003)$ \\
\hline 2014 & $-4.3 \%$ & $3.8 \%$ & $(0.001)$ & $(0.002)$ & $-5.1 \%$ & $-0.7 \%$ & $(0.001)$ & $(0.002)$ & $1.1 \%$ & $4.5 \%$ & $(0.015)$ & $(0.030)$ \\
\hline
\end{tabular}


Table 7. Year-by-year Spearman correlation between industry $q$ and industry funding rate, without repurchasers

The industries are the Fama-French 48 industries. The funding rate of an industry is the sum of all equity and debt funds raised by the industry's firms during the year, divided by the sum of those firms' total assets at the start of the year. The equity (debt) funding rate of an industry is the sum of all equity (debt) raised by the industry's firms during the year, divided by the sum of those firms' total assets at the start of the year. The industry $\mathrm{q}$ is the ratio of market value of assets to book value of assets, all at the end of the previous year. We exclude stock repurchasers from the sample and the ranking-based correlation coefficient is estimated every year across those repurchaser-free industries. 


\begin{tabular}{|c|c|c|c|c|c|c|}
\hline \multirow{2}{*}{ year } & \multicolumn{5}{|c|}{ Spearman correlation between industry $\mathrm{q}$ and: } & \multirow[b]{2}{*}{ p-value } \\
\hline & total funding rate & $\mathrm{p}$-value & equity funding rate & p-value & debt funding rate & \\
\hline 1971 & 0.116 & $(0.494)$ & 0.115 & $(0.496)$ & 0.041 & $(0.809)$ \\
\hline 1972 & 0.150 & $(0.363)$ & 0.394 & $(0.013)$ & 0.034 & $(0.837)$ \\
\hline 1973 & -0.037 & $(0.823)$ & 0.265 & $(0.103)$ & -0.131 & $(0.425)$ \\
\hline 1974 & 0.349 & $(0.029)$ & 0.258 & $(0.113)$ & 0.296 & $(0.067)$ \\
\hline 1975 & 0.242 & $(0.132)$ & 0.620 & $<.0001$ & 0.101 & $(0.534)$ \\
\hline 1976 & 0.085 & $(0.602)$ & 0.086 & $(0.597)$ & 0.112 & $(0.491)$ \\
\hline 1977 & 0.167 & $(0.311)$ & -0.069 & $(0.677)$ & 0.145 & $(0.377)$ \\
\hline 1978 & 0.237 & $(0.147)$ & 0.081 & $(0.622)$ & 0.259 & $(0.112)$ \\
\hline 1979 & 0.110 & $(0.509)$ & 0.016 & $(0.926)$ & 0.140 & $(0.401)$ \\
\hline 1980 & 0.321 & $(0.050)$ & 0.282 & $(0.086)$ & 0.264 & $(0.109)$ \\
\hline 1981 & 0.451 & $(0.005)$ & 0.421 & $(0.009)$ & 0.191 & $(0.250)$ \\
\hline 1982 & 0.285 & $(0.083)$ & 0.515 & $(0.001)$ & 0.074 & $(0.659)$ \\
\hline 1983 & 0.560 & $(0.000)$ & 0.512 & $(0.001)$ & 0.356 & $(0.029)$ \\
\hline 1984 & 0.417 & $(0.009)$ & 0.479 & $(0.002)$ & 0.340 & $(0.037)$ \\
\hline 1985 & 0.481 & $(0.002)$ & 0.509 & $(0.001)$ & 0.419 & $(0.008)$ \\
\hline 1986 & 0.373 & $(0.019)$ & 0.453 & $(0.004)$ & 0.116 & $(0.481)$ \\
\hline 1987 & 0.200 & $(0.216)$ & 0.216 & $(0.181)$ & 0.128 & $(0.430)$ \\
\hline 1988 & 0.364 & $(0.023)$ & 0.372 & $(0.020)$ & 0.315 & $(0.051)$ \\
\hline 1989 & 0.357 & $(0.026)$ & 0.384 & $(0.016)$ & 0.247 & $(0.130)$ \\
\hline 1990 & 0.152 & $(0.354)$ & 0.527 & $(0.001)$ & 0.015 & $(0.930)$ \\
\hline 1991 & 0.273 & $(0.092)$ & 0.278 & $(0.086)$ & 0.058 & $(0.726)$ \\
\hline 1992 & 0.476 & $(0.002)$ & 0.433 & $(0.005)$ & 0.176 & $(0.277)$ \\
\hline 1993 & 0.541 & $(0.000)$ & 0.444 & $(0.004)$ & 0.338 & $(0.033)$ \\
\hline 1994 & 0.463 & $(0.003)$ & 0.593 & $<.0001$ & 0.356 & $(0.026)$ \\
\hline 1995 & 0.244 & $(0.124)$ & 0.410 & $(0.008)$ & -0.039 & $(0.807)$ \\
\hline 1996 & 0.433 & $(0.005)$ & 0.598 & $<.0001$ & 0.098 & $(0.542)$ \\
\hline 1997 & -0.003 & $(0.985)$ & 0.337 & $(0.033)$ & -0.210 & $(0.193)$ \\
\hline 1998 & 0.188 & $(0.245)$ & 0.417 & $(0.008)$ & 0.007 & $(0.967)$ \\
\hline 1999 & 0.010 & $(0.952)$ & 0.351 & $(0.026)$ & -0.202 & $(0.212)$ \\
\hline 2000 & 0.592 & $<.0001$ & 0.620 & $<.0001$ & 0.405 & $(0.010)$ \\
\hline 2001 & 0.312 & $(0.050)$ & 0.324 & $(0.042)$ & 0.171 & $(0.290)$ \\
\hline 2002 & 0.242 & $(0.138)$ & 0.490 & $(0.002)$ & 0.133 & $(0.419)$ \\
\hline 2003 & 0.498 & $(0.001)$ & 0.485 & $(0.001)$ & 0.210 & (0.189) \\
\hline 2004 & 0.220 & $(0.167)$ & 0.456 & $(0.003)$ & -0.133 & $(0.407)$ \\
\hline 2005 & 0.225 & $(0.157)$ & 0.330 & $(0.035)$ & 0.119 & $(0.459)$ \\
\hline 2006 & 0.318 & $(0.043)$ & 0.333 & $(0.034)$ & 0.250 & $(0.115)$ \\
\hline 2007 & 0.434 & $(0.005)$ & 0.339 & $(0.030)$ & 0.390 & $(0.012)$ \\
\hline 2008 & 0.111 & $(0.497)$ & 0.418 & $(0.007)$ & 0.020 & $(0.905)$ \\
\hline 2009 & 0.360 & $(0.022)$ & 0.294 & $(0.065)$ & 0.236 & $(0.143)$ \\
\hline 2010 & 0.015 & $(0.927)$ & 0.189 & $(0.244)$ & -0.048 & $(0.767)$ \\
\hline 2011 & 0.066 & $(0.692)$ & 0.284 & $(0.080)$ & 0.020 & $(0.904)$ \\
\hline 2012 & 0.013 & $(0.935)$ & 0.059 & $(0.718)$ & 0.081 & $(0.621)$ \\
\hline 2013 & -0.035 & $(0.832)$ & -0.013 & $(0.935)$ & -0.044 & $(0.787)$ \\
\hline 2014 & 0.064 & $(0.705)$ & 0.202 & $(0.224)$ & -0.122 & $(0.465)$ \\
\hline
\end{tabular}


Table 8. Panel regressions of industry total funding rate on industry $q$ - without repurchasers This table shows the panel regressions of the industry total funding rate on industry q and control variables, with repurchasers omitted in the years in which they repurchase equity. All other specifications are the same as those in Table 5.

Panel A. Entire sample period (1971 2014)

\begin{tabular}{|c|c|c|c|}
\hline \multirow[b]{2}{*}{ regressors } & \multicolumn{3}{|c|}{ dependent variable: industry total funding rate } \\
\hline & Est. (p-val) & Est. (p-val) & Est. (p-val) \\
\hline industry $\mathrm{q}$ & $0.038 \quad(0.000)$ & $0.036(0.000)$ & $0.030(0.000)$ \\
\hline concurrent cashflow & $-0.559(0.019)$ & $-0.813(0.025)$ & $-0.597(0.000)$ \\
\hline lagged cashflow & $0.518(0.044)$ & $0.270(0.115)$ & $0.224(0.023)$ \\
\hline lagged capex & & & $-0.051 \quad(0.531)$ \\
\hline concurrent capex & & $0.910(0.066)$ & $0.575(0.004)$ \\
\hline lead capex & & & $-0.091 \quad(0.333)$ \\
\hline \# observations & 1736 & 1736 & 1666 \\
\hline$R^{2}$ & $2.8 \%$ & $9.5 \%$ & $15.2 \%$ \\
\hline
\end{tabular}

Panel B. First sub-period (1971 1996)

\begin{tabular}{|c|c|c|c|}
\hline \multirow[b]{2}{*}{ regressors } & \multicolumn{3}{|c|}{ dependent variable: industry total funding rate } \\
\hline & Est. (p-val) & Est. (p-val) & Est. (p-val) \\
\hline industry q & $0.043(0.011)$ & $0.030(0.056)$ & $0.023(0.007)$ \\
\hline concurrent cashflow & $-0.741(0.085)$ & $-1.185(0.106)$ & $-0.719(0.000)$ \\
\hline lagged cashflow & $0.633(0.169)$ & $0.323(0.331)$ & $0.180 \quad(0.317)$ \\
\hline lagged capex & & & $0.046(0.533)$ \\
\hline concurrent capex & & $1.214(0.124)$ & $0.420(0.006)$ \\
\hline lead capex & & & $0.028 \quad(0.797)$ \\
\hline \# observations & 1015 & 1015 & 993 \\
\hline$R^{2}$ & $2.2 \%$ & $10.3 \%$ & $20.3 \%$ \\
\hline
\end{tabular}

Panel C. Second sub-period (1997 2014)

\begin{tabular}{|c|c|c|c|}
\hline \multirow[b]{2}{*}{ regressors } & \multicolumn{3}{|c|}{ dependent variable: industry total funding rate } \\
\hline & Est. (p-val) & Est. (p-val) & Est. (p-val) \\
\hline industry q & $0.035(0.003)$ & $0.037(0.001)$ & $0.036(0.002)$ \\
\hline concurrent cashflow & $-0.316(0.099)$ & $-0.393(0.029)$ & $-0.431 \quad(0.007)$ \\
\hline lagged cashflow & $0.325(0.095)$ & $0.176(0.320)$ & $0.263(0.142)$ \\
\hline lagged capex & & & $-0.221(0.190)$ \\
\hline concurrent capex & & $0.504(0.006)$ & $0.867 \quad(0.065)$ \\
\hline lead capex & & & $-0.267 \quad(0.197)$ \\
\hline \# observations & 721 & 721 & 673 \\
\hline$R^{2}$ & $7.2 \%$ & $12.8 \%$ & $14.8 \%$ \\
\hline
\end{tabular}




\section{Figure 1. Median industry q of "low-funded" and "high-funded" industry quintiles from 1971 to}

2014

Each year, the Fama-French 48 industries for which we have data are sorted into quintiles based on their funding rates. The funding rate of an industry is the sum of all equity and debt funds raised by the industry's firms during the year, divided by the sum of those firms' total assets at the start of the year. The "lowfunded" and "high-funded" quintiles are, respectively, the quintiles of industries that are the least and most funded during the year. The industry $q$ is the ratio of the market value of assets of the industry (i.e., book value of assets - book value of equity + market value of equity) to the book value of assets of the industry at the end of the previous year.

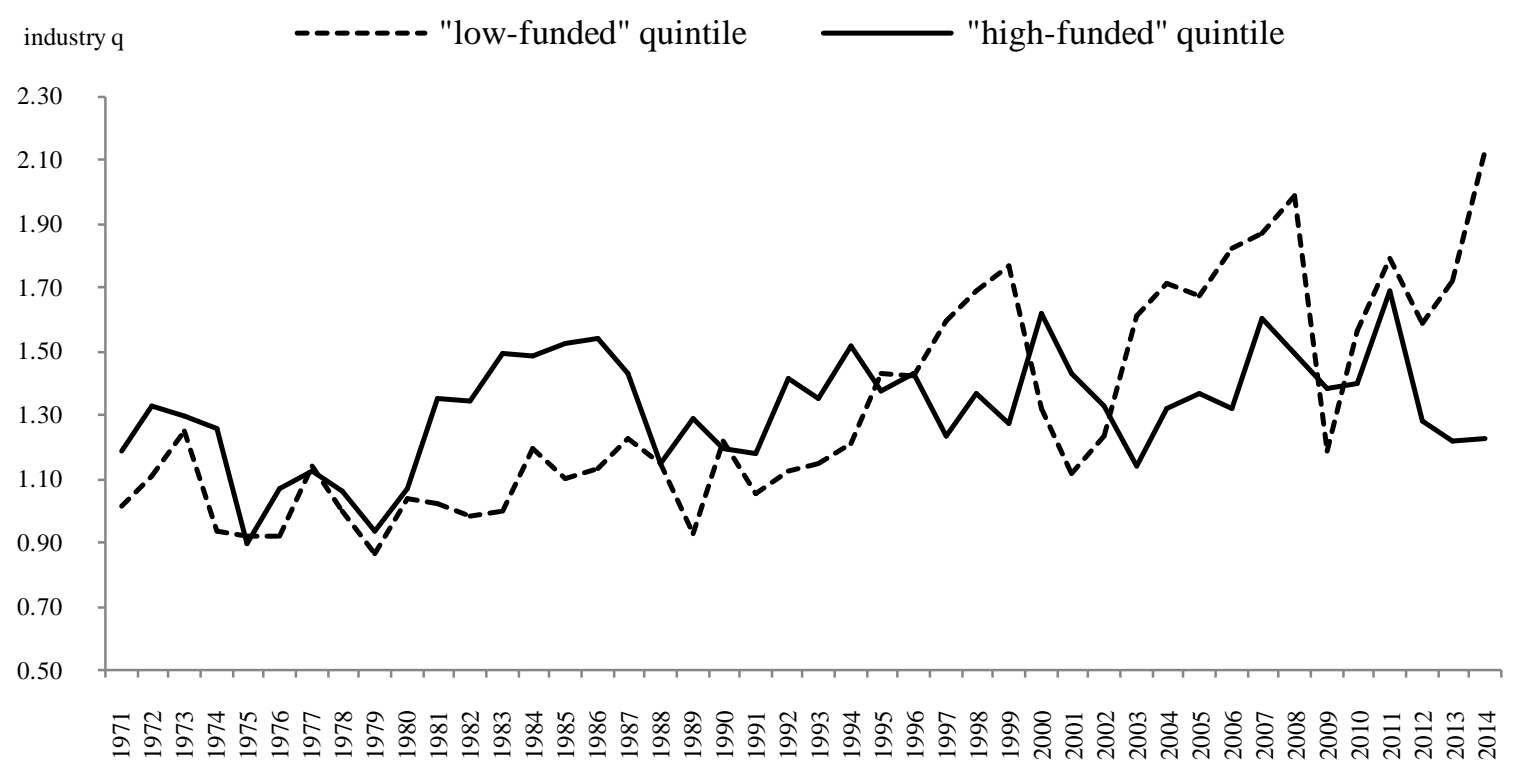


Figure 2. Year-by-year Spearman correlation between industry $q$ and industry total funding rate from 1971 to 2014

Each year, the Fama-French 48 industries for which we have data are sorted into quintiles based on their funding rates. The funding rate of an industry is the sum of all equity and debt funds raised by the industry's firms during the year, divided by the sum of those firms' total assets at the start of the year. The industry q is the ratio of the market value of assets of the industry (i.e., book value of assets - book value of equity + market value of equity) to the book value of assets of the industry at the end of the previous year. The correlation coefficient is estimated every year across sample industries.

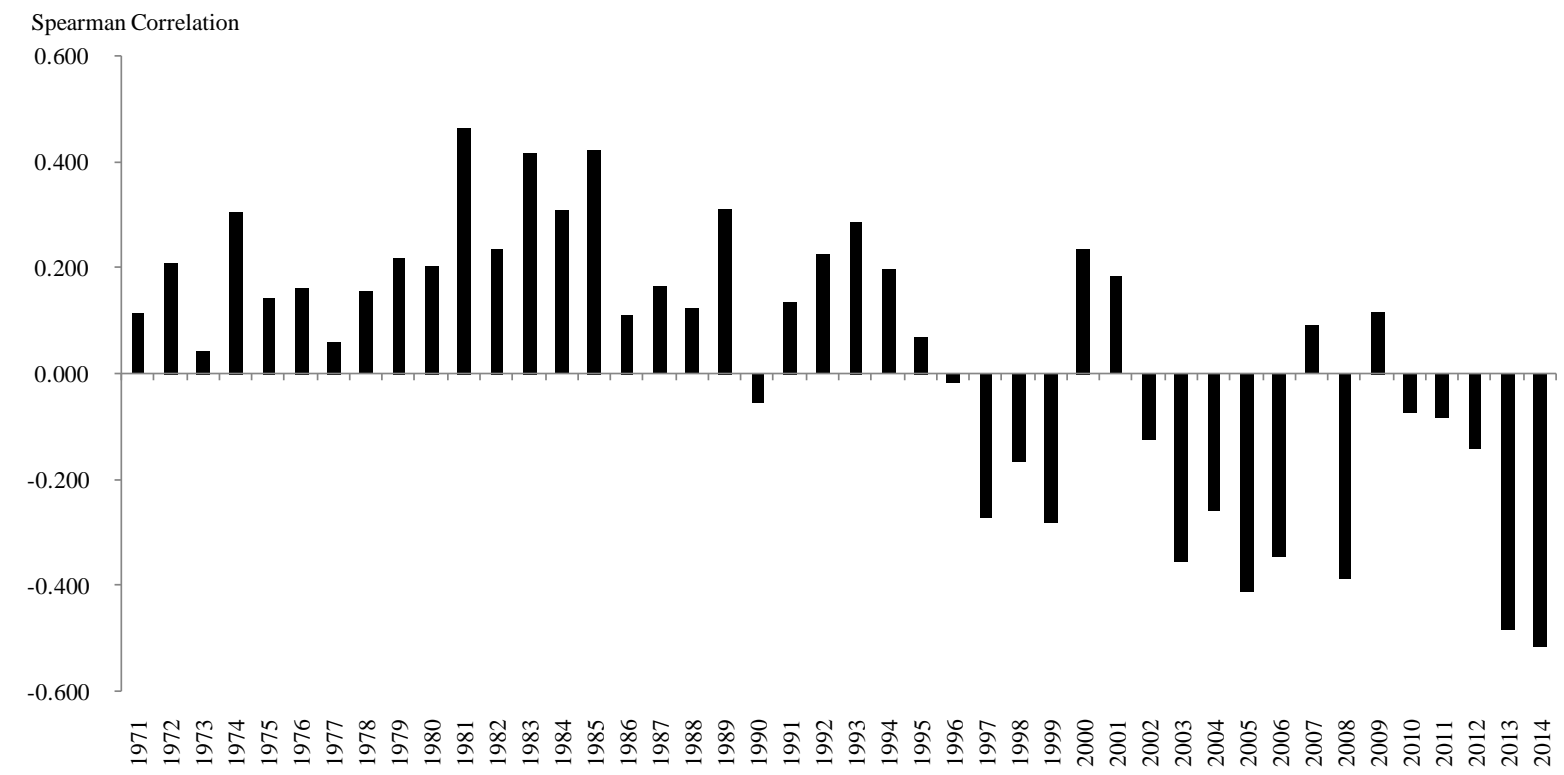


Figure 3. Year-by-year Spearman correlation between alternative industry q ratios and industry funding rate (total, equity, or debt) from 1971 to 2014

The sample period is from 1971 to 2014. The industries are the Fama-French 48 industries. The funding rate of an industry is the sum of all equity and debt funds raised by the industry's firms during the year, divided by the sum of those firms' total assets at the start of the year. Conventional $q$ is the ratio of the market value of equity plus the book value of long-term and short-term debt minus the book value of current assets to the book value of property, plant, and equipment. PT q is similarly defined, except that the denominator additionally includes the value of intangible assets, which we obtain from Peters and Taylor (2016). The correlation coefficient between each of the two q ratios and the industry funding rate is estimated every year across sample industries.

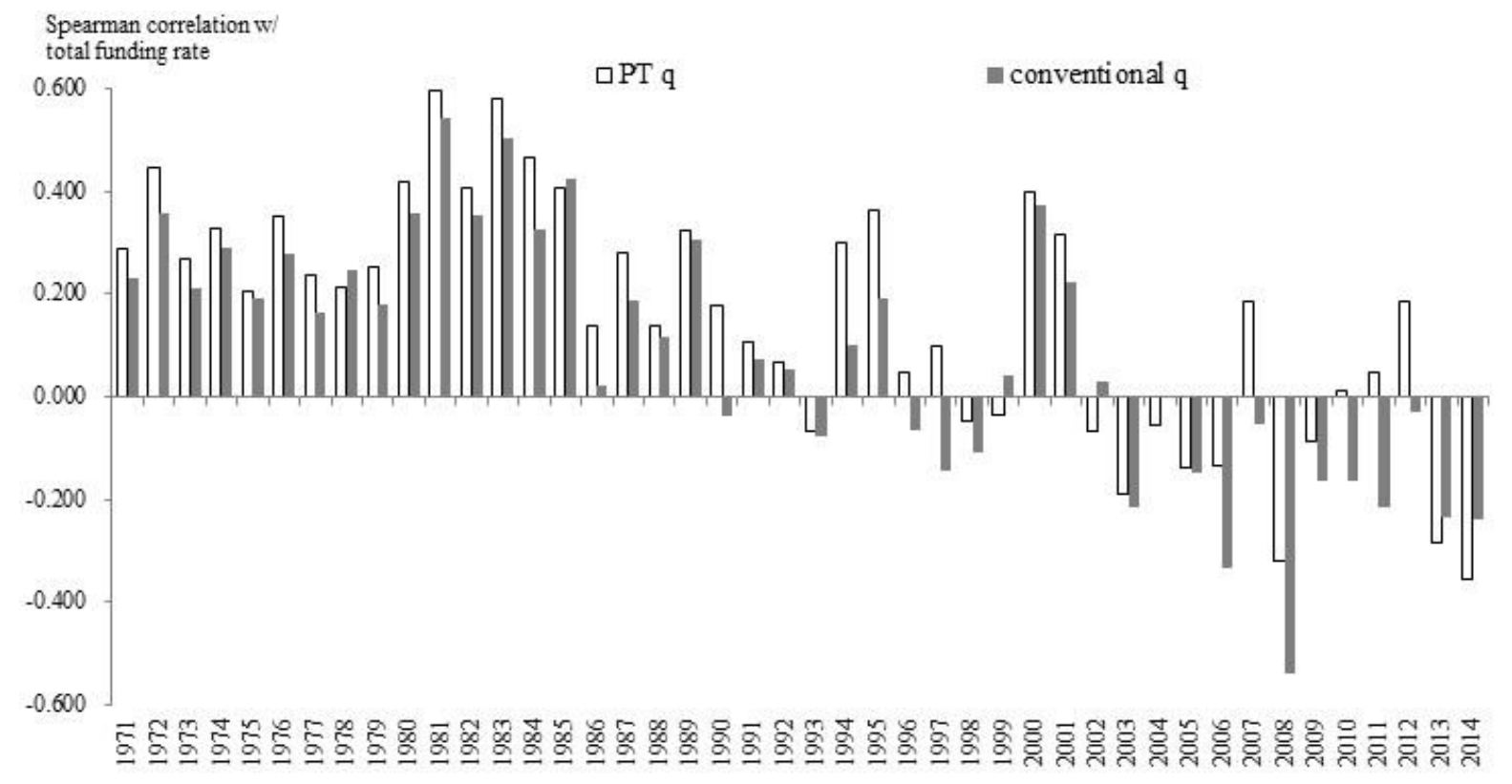


Figure 4. Year-by-year Spearman correlation between industry $q$ and industry capital expenditures from 1971 to 2014

Each year, the Fama-French 48 industries for which we have data are sorted into quintiles based on their funding rates. Capital expenditures of an industry are the sum of all capital expenditures spent by the industry's firms during the year, divided by the sum of those firms' total assets at the start of the year. The industry $q$ is the ratio of the market value of assets of the industry (i.e., book value of assets - book value of equity + market value of equity) to the book value of assets of the industry at the end of the previous year. The correlation coefficient is estimated every year across sample industries.

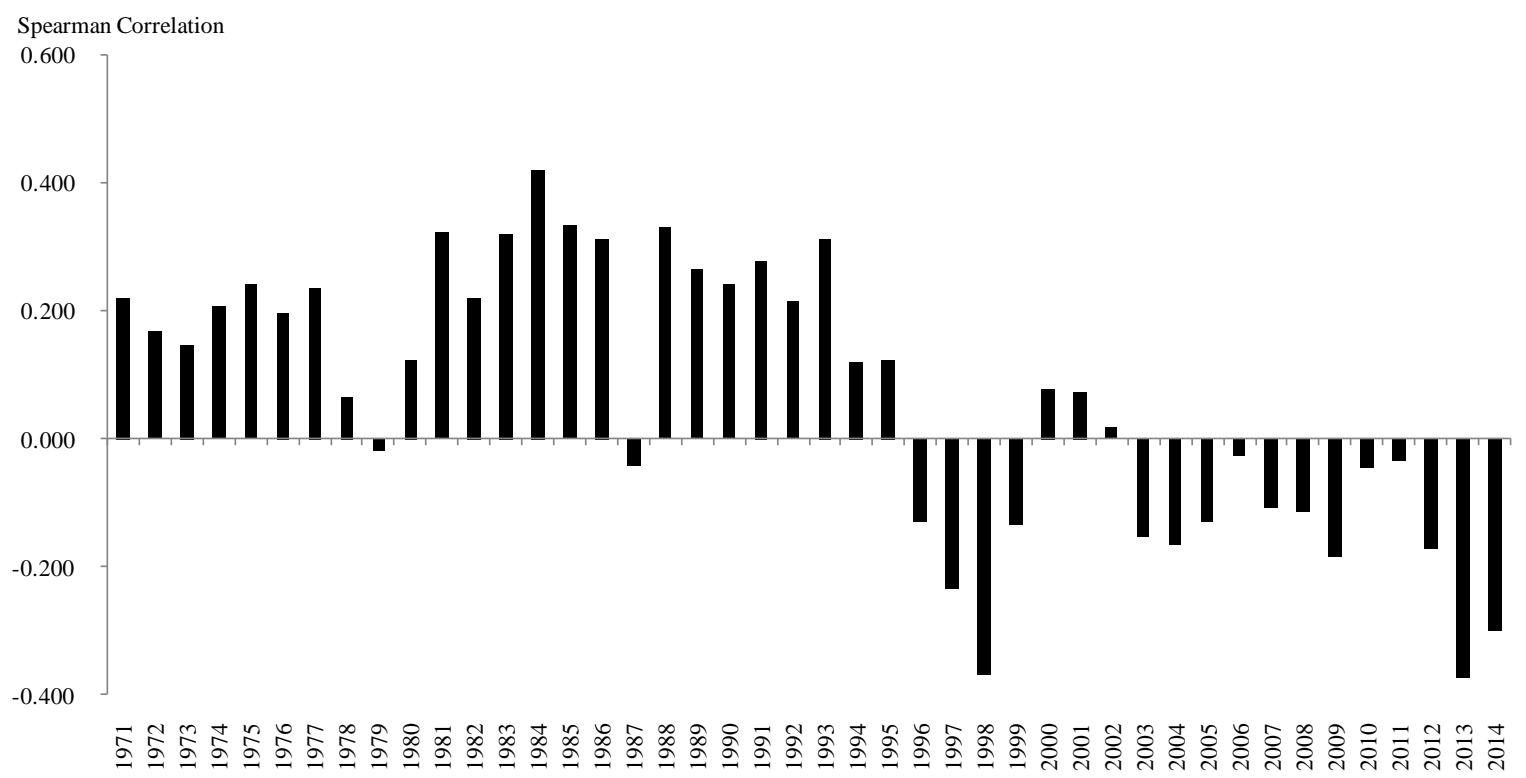


Figure 5. Aggregate corporate cash flows, net investment, and external funding from 1971 to 2014 This figure shows the decomposition of corporate total external funding into cash dividends, changes in net working capital, net investment, and internal cash flows (after tax and interests), based on Frank and Goyal's (2003) method.Net investment is capital expenditures plus increase in investments plus acquisitions plus other use of funds minus sale of PPE and sale of investments.

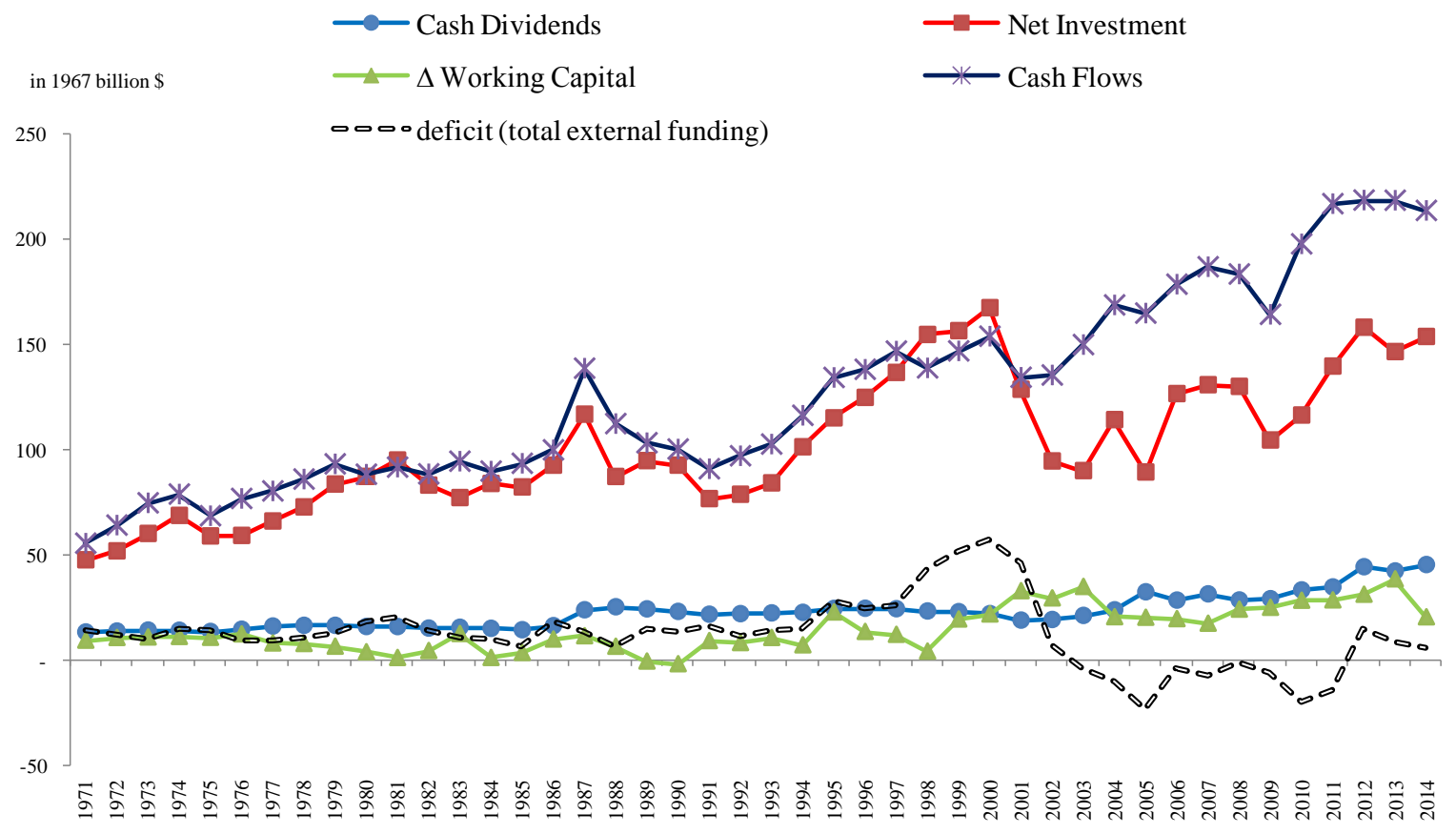


Figure 6. Decomposition of aggregate external funding into equity and debt funds

This figure shows the decomposition of aggregate corporate total external funding into equity funding and debt funding.

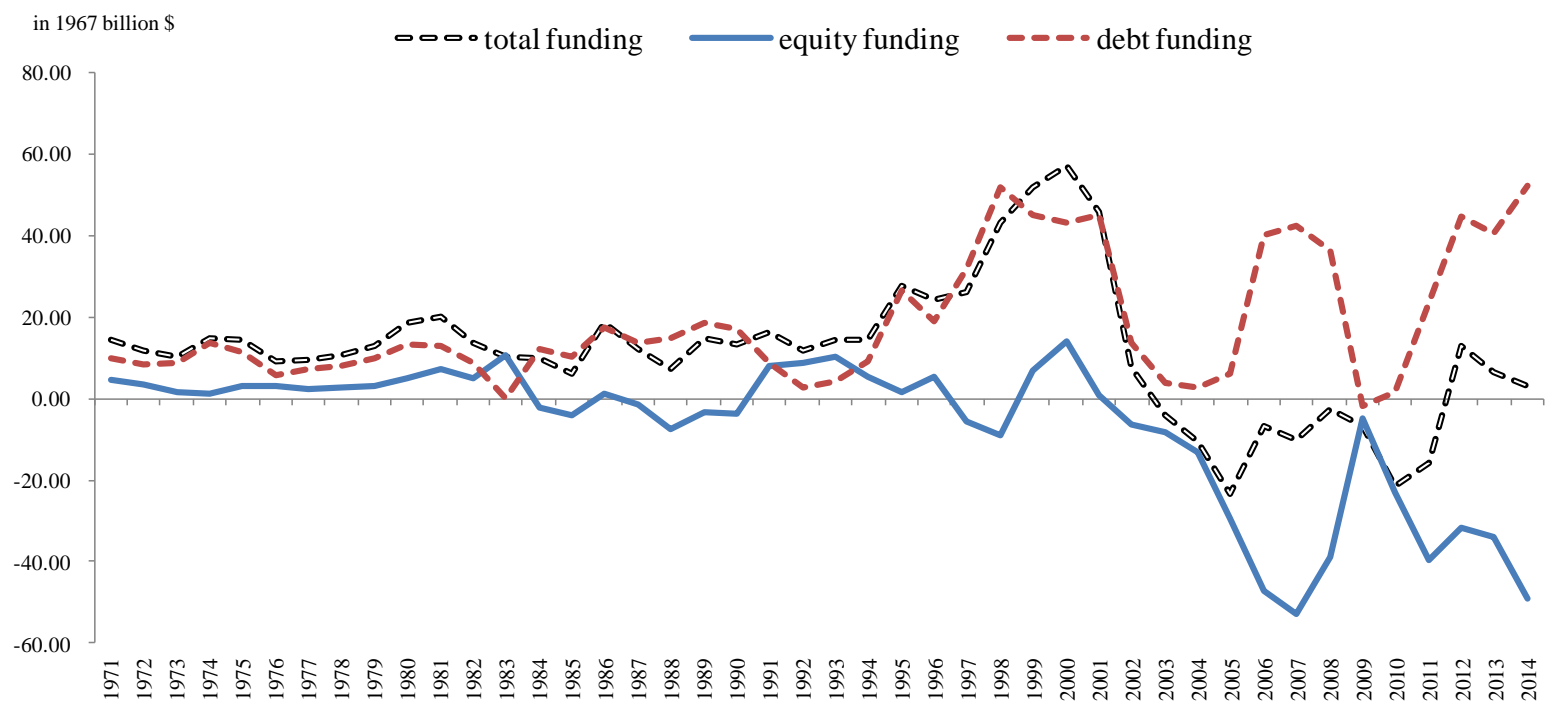


Figure 7. Year-by-year Spearman correlation between industry $q$ and industry equity or debt funding rate from 1971 to 2014

The industries are the Fama-French 48 industries. The equity (debt) funding rate of an industry is the sum of all equity (debt) raised by the industry's firms during the year, divided by the sum of those firms' total assets at the start of the year. The industry $q$ is the ratio of market value of assets to book value of assets, all at the end of the previous year. The figures below show the ranking-based correlation coefficient between industry q-ratio and industry equity (top panel) or debt (bottom panel) funding rate. The coefficient is estimated every year across sample industries.

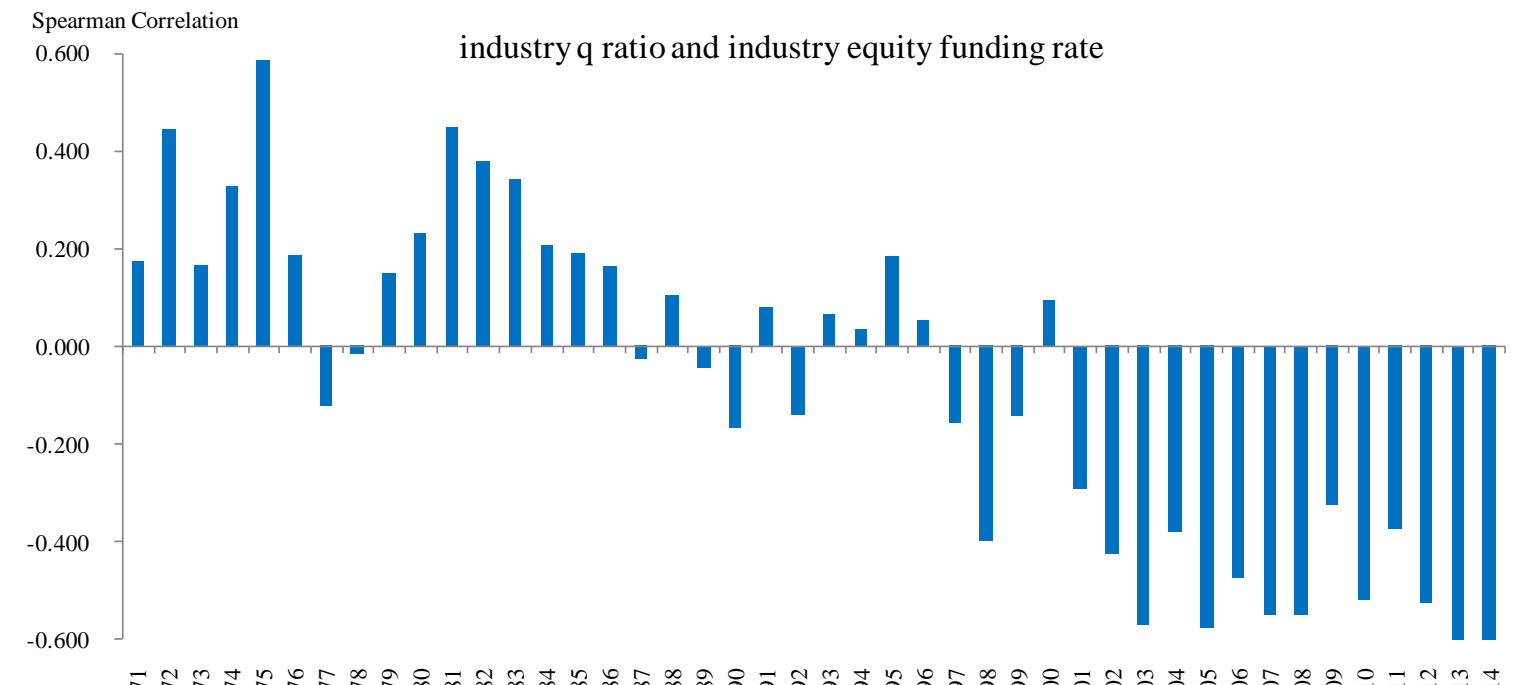

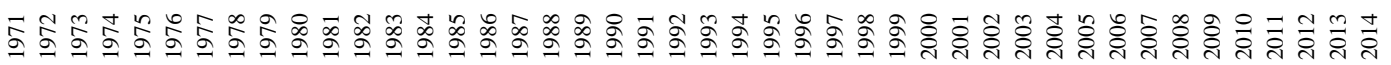

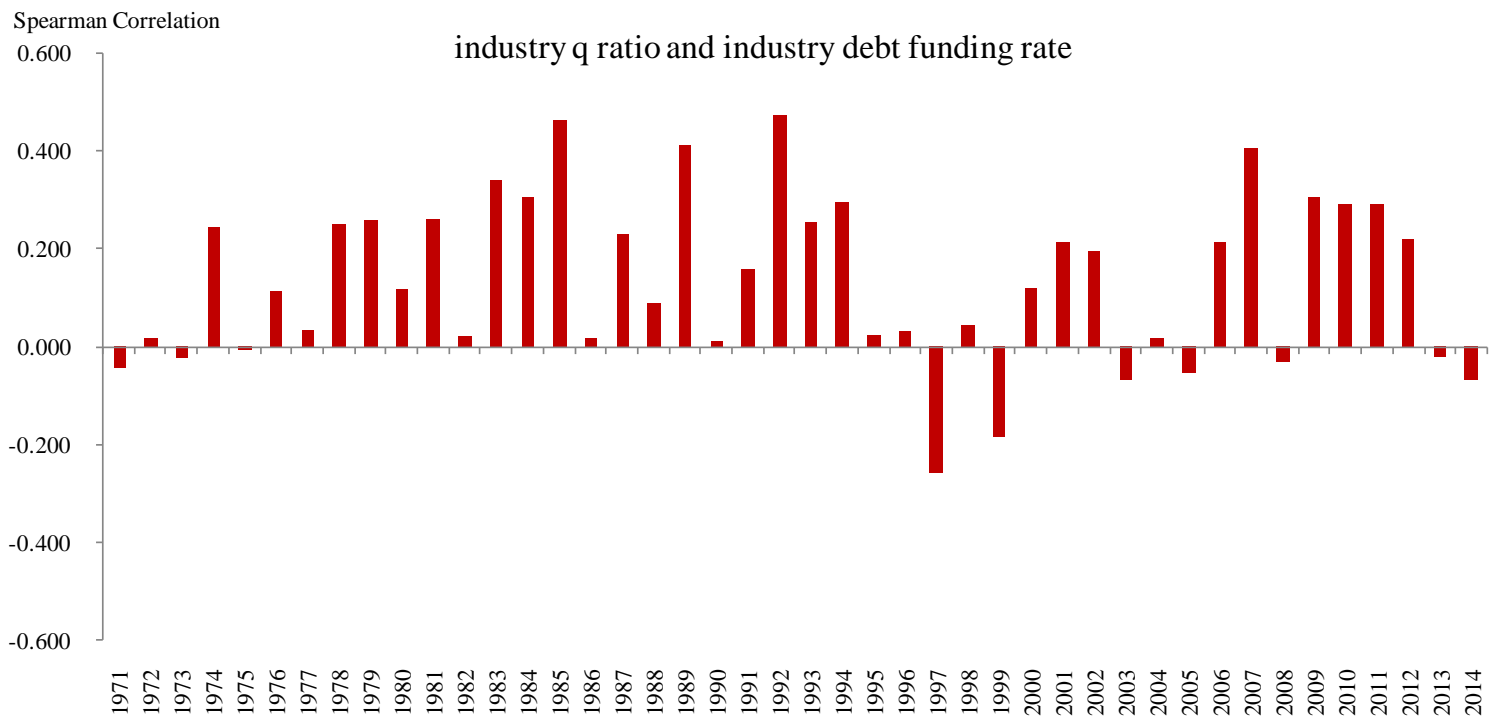




\section{Figure 8. Median industry q ratio of "low-equity (debt) funded" and "high-equity (debt) funded"}

industry quintiles from 1971 to 2014

The industries are the Fama-French 48 industries. The equity (debt) funding rate of an industry is the sum of all equity (debt) funds raised by the industry's firms during the year, divided by the sum of the firms' total assets at the start of the year. The industry q is the ratio of market value of assets to book value of assets, all at the end of the previous year. The figures below show the median industry q of the "low-equity (debt) funded" and "high-equity (debt) funded" industry quintiles. Each year, sample industries are sorted into quintiles based on their equity (debt) funding rates, and the "low-equity (debt) funded" and "highequity (debt) funded" quintiles are, respectively, the group of industries that are least and most funded by equity (debt) during the year.
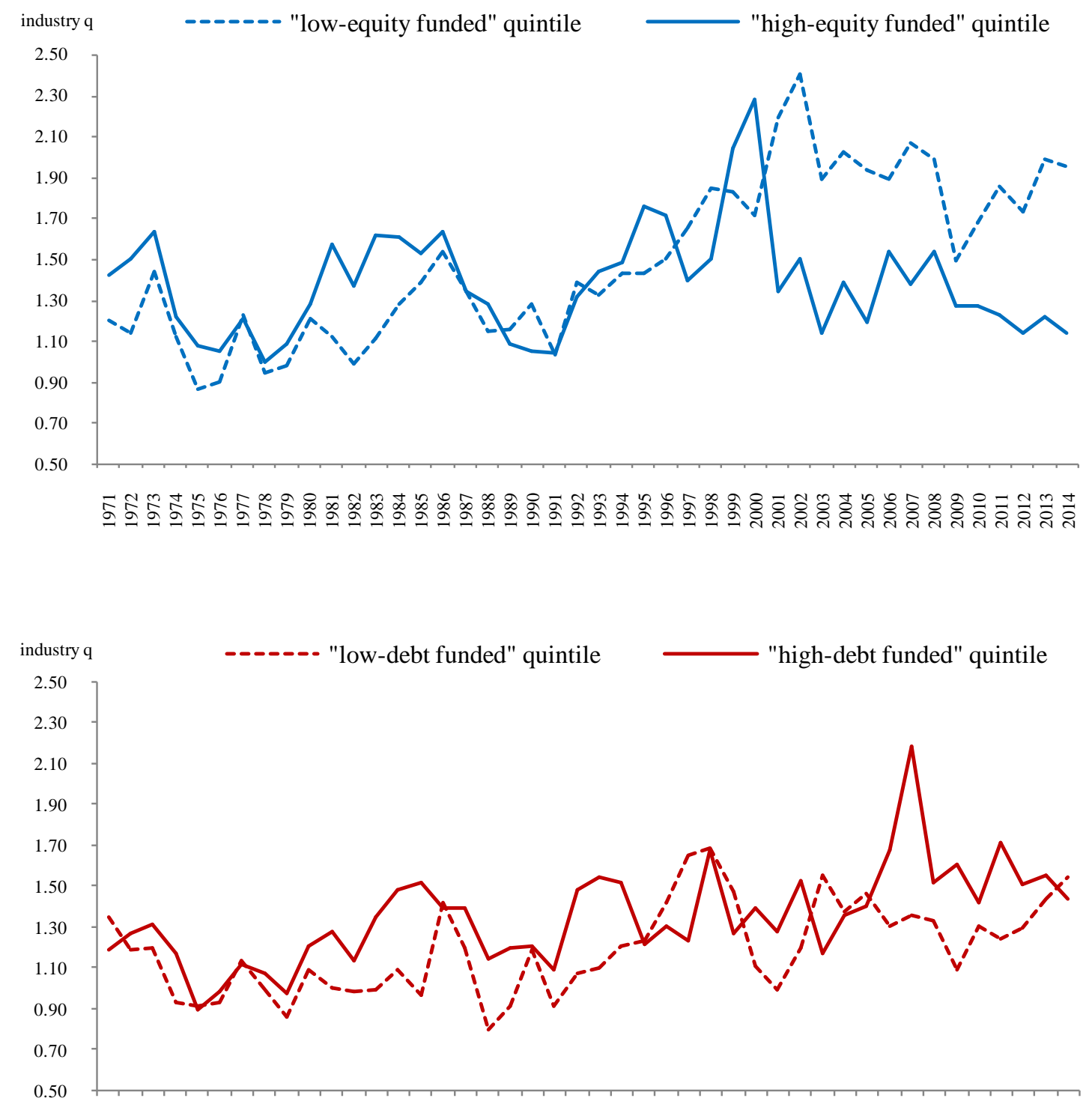

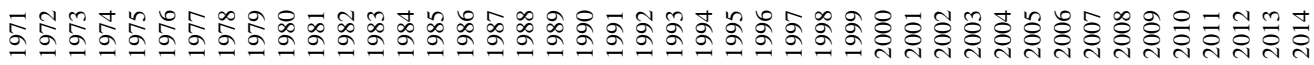


Figure 9. Dollar repurchases versus dollar excess of cash flow over net investment from 1971 to 2014

Each year, we add across the firms in our sample the dollar amount of repurchases, the dollar amount of excess of cash flow over net investment, and the dollar amount of repurchases plus the dollar amount of change in cash.

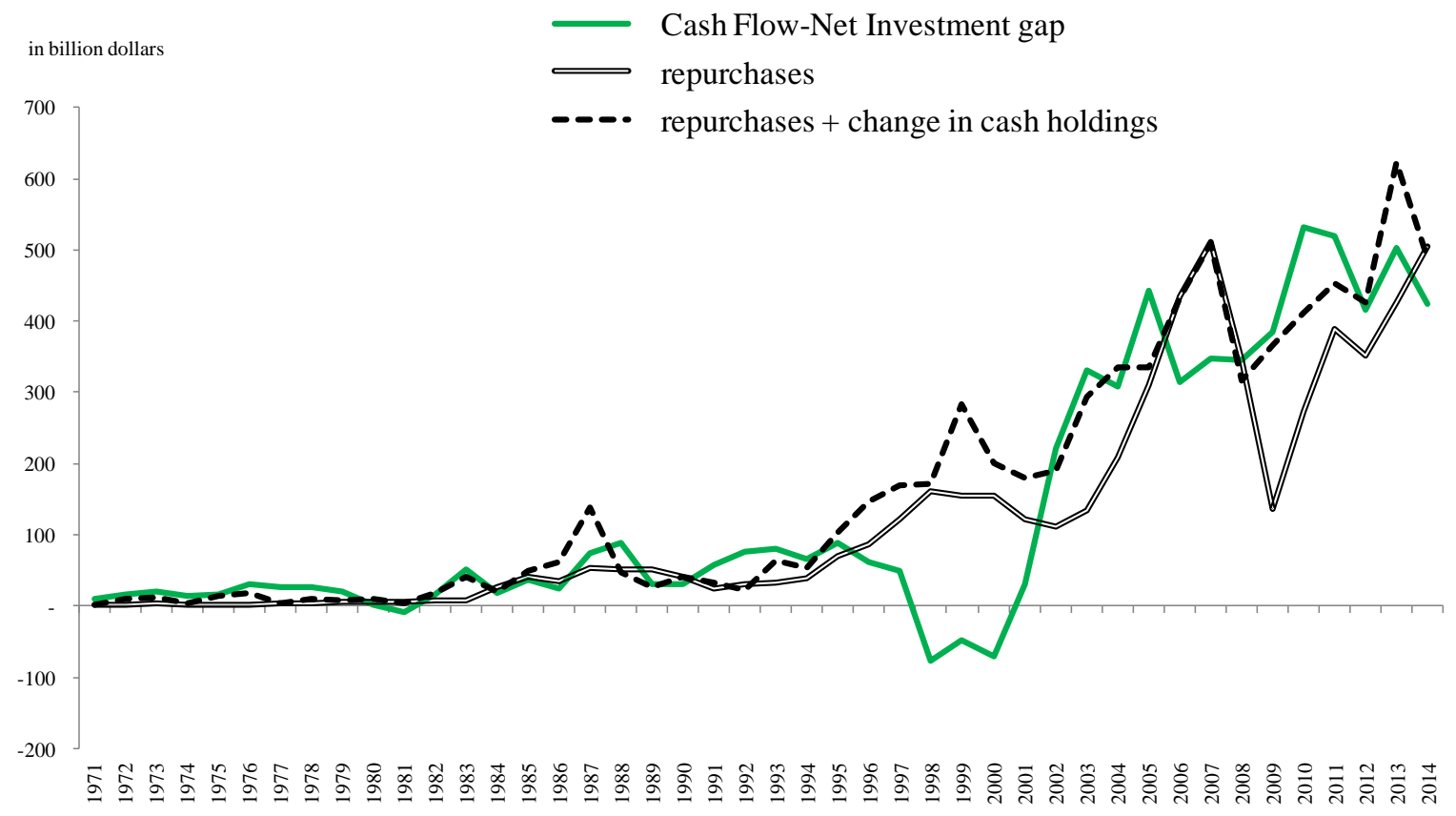


Figure 10. Year-by-year Spearman correlation of industry q with industry repurchases from 1971 to 2014

The industries are the Fama-French 48 industries. The industry q is the ratio of market value of assets to book value of assets, all at the end of the previous year. Within an industry, repurchases are summed across companies within an industry each year.

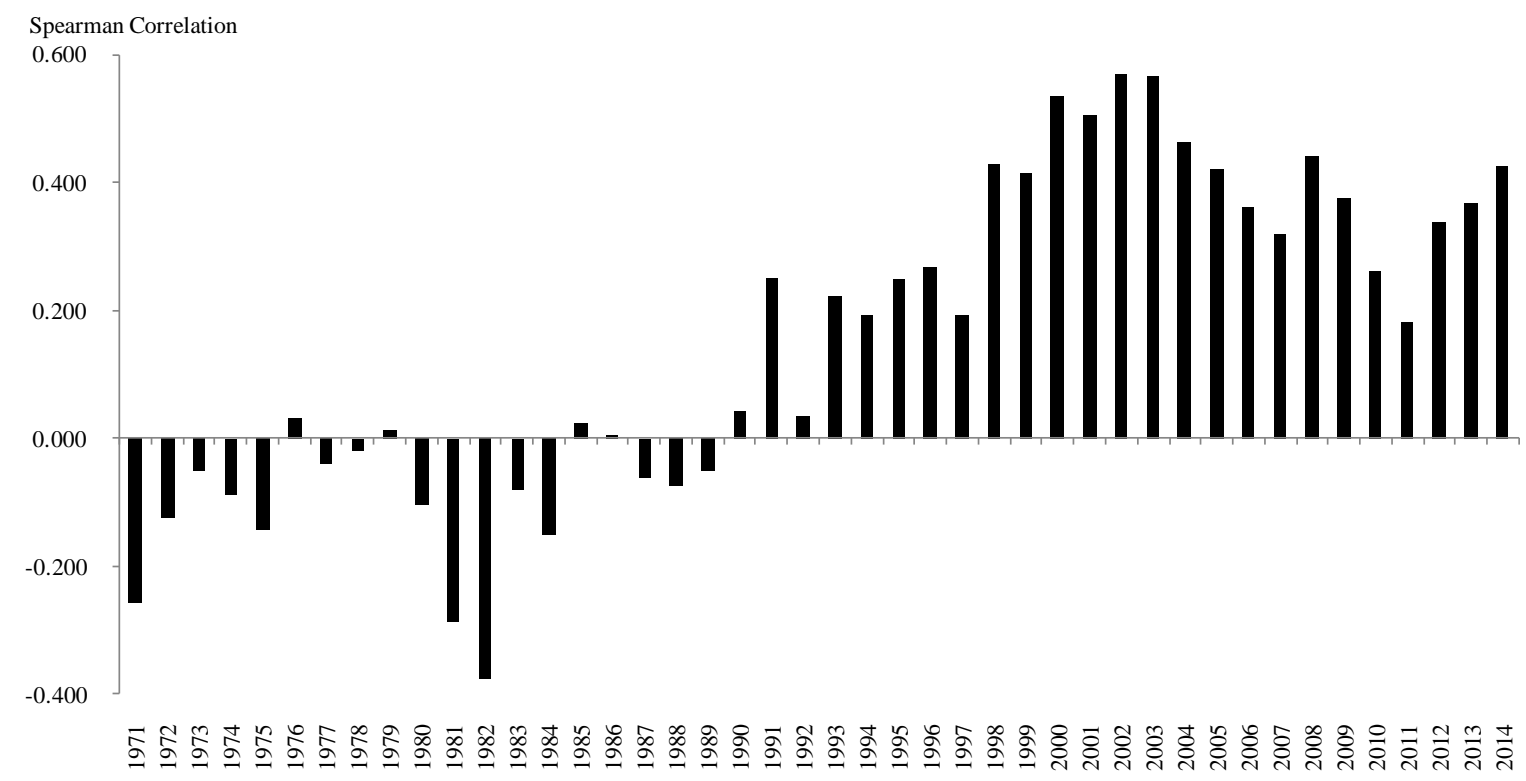

